\title{
Characterization of tumor-associated T-lymphocyte subsets and immune checkpoint molecules in head and neck squamous cell carcinoma
}

\author{
Axel Lechner ${ }^{1,2, *}$, Hans Schlößer ${ }^{1,3, *}$, Sacha I. Rothschild ${ }^{1,4, *}$, Martin Thelen ${ }^{1}$, \\ Sabrina Reuter ${ }^{1}$, Peter Zentis ${ }^{5}$, Alexander Shimabukuro-Vornhagen ${ }^{1,6}$, Sebastian \\ Theurich $^{1,6,7}$, Kerstin Wennhold ${ }^{1}$, Maria Garcia-Marquez ${ }^{1}$, Lars Tharun ${ }^{8}$, Alexander \\ Quaas $^{8}$, Astrid Schauss 5 , Jörg Isensee ${ }^{9}$, Tim Hucho ${ }^{9}$, Christian Huebbers $^{10}$, Michael \\ von Bergwelt-Baildon ${ }^{1,6, *}$ and Dirk Beutner ${ }^{2, *}$

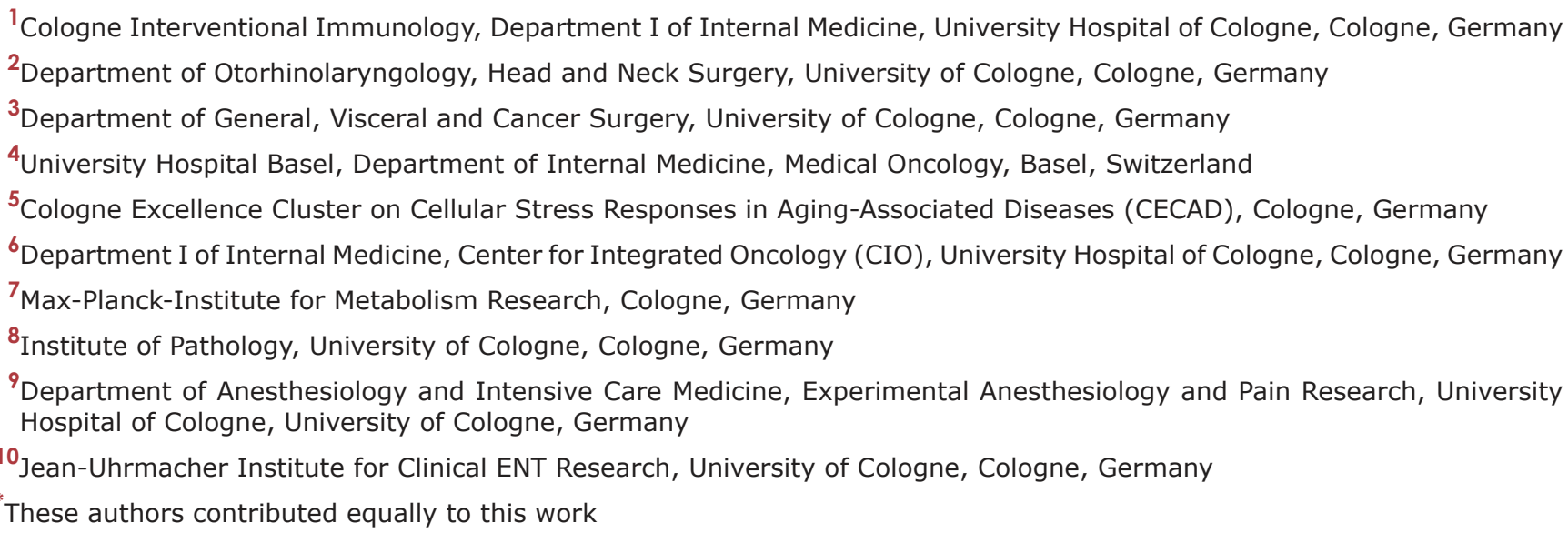

Correspondence to: Michael von Bergwelt-Baildon, email: michael.bergwelt@uk-koeln.de

Keywords: squamous cell carcinoma, head and neck, microenvironment, $T$ cells, immune checkpoint

Received: January 10, 2017 Accepted: April 25, $2017 \quad$ Published: May 16, 2017

Copyright: Lechner et al. This is an open-access article distributed under the terms of the Creative Commons Attribution License 3.0 (CC BY 3.0), which permits unrestricted use, distribution, and reproduction in any medium, provided the original author and source are credited.

\section{ABSTRACT}

The composition of tumor-infiltrating lymphocytes (TIL) reflects biology and immunogenicity of cancer. Here, we characterize T-cell subsets and expression of immune checkpoint molecules in head and neck squamous cell carcinoma (HNSCC). We analyzed TIL subsets in primary tumors $(n=34)$, blood (peripheral blood mononuclear cells (PBMC); $n=34$ ) and non-cancerous mucosa $(n=7)$ of 34 treatment-naïve HNSCC patients and PBMC of 15 healthy controls. Flow cytometry analyses revealed a highly variable T-cell infiltration mainly of an effector memory phenotype (CD45RA- $\left.{ }^{-} \mathrm{CCR7}^{-}\right)$. Naïve T cells $\left(\mathrm{CD}^{2} 5 \mathrm{RA}^{+} / \mathrm{CCR7}^{+}\right)$were decreased in the microenvironment compared to PBMC of patients, while regulatory $\mathrm{T}$ cells $\left(\mathrm{CD4}^{+}\right.$/ $\mathrm{CD25}^{+} / \mathrm{CD} 127^{\text {low }}$ and $\left.\mathrm{CD4}^{+} / \mathrm{CD} 9^{+}\right)$were elevated. Furthermore, we performed digital image analyses of entire cross sections of HNSCC to define the 'Immunoscore' (CD3' and $\mathrm{CDB}^{+}$cell infiltration in tumor core and invasive margin) and quantified MHC class I expression on tumor cells by immunohistochemistry. Immune checkpoint molecules cytotoxic T-lymphocyte-associated antigen 4 (CTLA-4), programmed cell death 1 (PD-1) and programmed cell death 1 ligand 1 (PD-L1) were increased in TILs compared to peripheral $\mathrm{T}$ cells in flow-cytometric analysis. Human papillomavirus (HPV) positive tumors showed higher numbers of TILs, but a similar composition of T-cell subsets and checkpoint molecule expression compared to HPV negative tumors. Taken together, the tumor microenvironment of HNSCC is characterized by a strong 


\section{infiltration of regulatory $\mathbf{T}$ cells and high checkpoint molecule expression on $\mathrm{T}$-cell subsets. In view of increasingly used immunotherapies, a detailed knowledge of TILs and checkpoint molecule expression on TILs is of high translational relevance.}

\section{INTRODUCTION}

Head and neck squamous cell carcinoma (HNSCC) is in most cases related to smoking and alcohol consumption [1]. However, the incidence of HNSCC associated with human papillomavirus (HPV) as an independent risk factor is increasing [2]. HPV positive HNSCC are associated with distinct clinical characteristics showing better response to chemoradiotherapy and improved prognosis compared to HPV negative tumors [3]. One explanation for the differing behavior of these two entities would be the difference in their tumor microenvironment with a distinct composition of tumorinfiltrating lymphocytes (TILs) that may facilitate an improved adaptive host immune response against viral antigens [4].

In recent years, it has been well established that the immune system plays a key role in the control of tumor growth and progression $[5,6]$. Tumor-infiltrating immune cells, including $\mathrm{T}$ and $\mathrm{B}$ lymphocytes, macrophages or neutrophils can either inhibit or enhance tumor growth. Our group recently investigated TILs in different solid tumors $[7,8]$. Regulatory T cells (Treg) are responsible for the control of autoreactive lymphocytes, but also downregulate the immune response to tumor-associated antigens. Presence of Treg has been reported among TILs and in the peripheral circulation in a variety of solid tumors [9-12]. In patients with HNSCC, the antitumor immune response is impaired and progression is associated with severe immune dysfunction [13]. However, infiltration by certain immune-effector cells is associated with favorable outcome [14]. Nevertheless, inconsistent results have been reported especially for Treg subsets $[15,16]$. Galon et al. established a strong correlation between type, density and location of TILs and the prognosis of cancer $[17,18]$. They proposed a standardized algorithm to determine antitumor immune responses using quantitative pathology. This 'Immunoscore' is based on the quantification of $\mathrm{CD}^{+}$and $\mathrm{CD} 8^{+}$TILs in the tumor core (CT) and the invasive margin (IM) and has proven to be a strong prognostic tool in colorectal cancer $[19,20]$. To date, an automated 'Immunoscore' analysis on entire cross sections of HNSCC has not been applied. Recently, it was demonstrated that immune cell infiltration patterns in non-small cell lung cancer differ depending on the degree of major histocompatibility complex (MHC) class I expression on tumor cells [21]. Furthermore, high MHC class I expression on tumor cells is associated with improved disease-free survival (DFS) in patients with HPV negative tonsillar squamous cell carcinoma compared to low MHC class I expression. However, this association is inverse in HPV positive tonsillar carcinoma [22].

Immune checkpoint molecules including cytotoxic T-lymphocyte-associated antigen 4 (CTLA-4), programmed cell death 1 (PD-1) and programmed cell death 1 ligand 1 (PD-L1) contribute to an immunosuppressive microenvironment in a variety of solid cancers. They can be expressed by several cells and are key molecules also for Treg [23, 24]. Specific antibodies targeting these molecules have recently changed the therapeutic landscape not only in head and neck cancer treatment [25].

A detailed characterization of the composition of the tumor microenvironment and of checkpoint molecule expression is crucial to understand mechanisms of immunotherapies.

\section{RESULTS}

\section{$\mathrm{CD}^{+} 5^{+}$lymphocyte count is highly variable in HNSCC}

We assessed the composition of TIL populations in tumor tissue of 34 previously untreated HNSCC patients (26 HPV negative tumors, $7 \mathrm{HPV}-16$-associated HNSCC, 1 HPV-35-associated HNSCC) by flow cytometry. Sample acquisition was conducted prior to initiation of anticancer treatment. Clinical characteristics of included patients are summarized in Table 1. The absolute number of $\mathrm{CD} 45^{+}$lymphocytes per microgram tissue was highly heterogeneous in HNSCC, ranging from $0.1 \mathrm{cells} / \mu \mathrm{g}$ to 44.2 cells $/ \mu \mathrm{g}$ with an average of $5.2 \pm 8.9 \mathrm{cells} / \mu \mathrm{g}$, which was significantly higher than the number of $\mathrm{CD} 45^{+}$cells in randomly biopsied non-cancerous mucosa samples $(n=7$, $0.3 \pm 0.2 / \mu \mathrm{g} ; p=0.004$; Figure $1 \mathrm{~A}$ )

\section{Tumor-infiltrating $\mathbf{T}$ cells are mainly of a $\mathrm{CD}^{2} \mathrm{RA}^{-} / \mathrm{CCR}^{-}$effector memory phenotype, while Treg are significantly increased}

$\mathrm{T}$ cells accounted for $78.8 \pm 10.9 \%$ of $\mathrm{CD} 45^{+}$ lymphocytes in tumor samples compared to $80.3 \pm 8.1 \%$ in non-cancerous mucosa, $62.7 \pm 5.9 \%$ in peripheral blood mononuclear cells (PBMC) of aged-matched healthy controls (PBMC HC, $n=15$ ) and $66.6 \pm 11.7 \%$ in peripheral blood samples of HNSCC patients (PBMC HNSCC; Figure 1B, left plot). No significant difference was detected in the percentage of $\mathrm{CD} 8^{+}$cytotoxic $\mathrm{T}$ cells in tumor samples $(30.9 \pm 18.7 \%$ of $\mathrm{T}$ cells $)$ compared to non-cancerous mucosa $(18.5 \pm 6.9 \%)$, PBMC HC 


\begin{tabular}{|c|c|c|}
\hline Characteristics & $N$ & $\%$ \\
\hline \multicolumn{3}{|l|}{ HNSCC patients $(n=34)$} \\
\hline Median age (range) & $68(49-85)$ & \\
\hline \multicolumn{3}{|l|}{ Sex } \\
\hline Male & 27 & $79 \%$ \\
\hline Female & 7 & $21 \%$ \\
\hline \multicolumn{3}{|l|}{ Localisation } \\
\hline Oral cavity & 5 & $14.7 \%$ \\
\hline Oropharynx & 16 & $47.1 \%$ \\
\hline Hypopharynx & 5 & $14.7 \%$ \\
\hline Larynx & 7 & $20.6 \%$ \\
\hline Other (nasal cavity) & 1 & $2.9 \%$ \\
\hline \multicolumn{3}{|l|}{ UICC stage } \\
\hline I & 2 & $5.9 \%$ \\
\hline II & 9 & $26.5 \%$ \\
\hline III & 6 & $17.6 \%$ \\
\hline IVA & 16 & $47.1 \%$ \\
\hline IVB & 0 & $0.0 \%$ \\
\hline IVC & 1 & $2.9 \%$ \\
\hline \multicolumn{3}{|l|}{ Histological grading } \\
\hline G1 & 0 & 0 \\
\hline G2 & 28 & $82 \%$ \\
\hline G3 & 6 & $18 \%$ \\
\hline \multicolumn{3}{|l|}{ HPV status } \\
\hline positive & 8 & $24 \%$ \\
\hline negative & 26 & $76 \%$ \\
\hline \multicolumn{3}{|l|}{ Healthy donors $(n=15)$} \\
\hline Median age (range) & $61(43-79)$ & \\
\hline \multicolumn{3}{|l|}{ Sex } \\
\hline Male & 12 & $80 \%$ \\
\hline Female & 3 & $20 \%$ \\
\hline
\end{tabular}

$\overline{\mathrm{HNSCC}}=$ head and neck squamous cell carcinoma; HPV = human papillomavirus; RT = radiotherapy; UICC $=$ Union for International Cancer Control.

$(24.6 \pm 9.9 \%)$ or PBMC HNSCC $(24.0 \pm 14.0 \%$; Figure $1 \mathrm{~B}$, right plot). However, the percentage of $\mathrm{CD}^{+} \mathrm{T}$ cells was significantly decreased in tumor samples $(54.7 \pm$ $19.6 \%)$ and mucosa $(45.3 \pm 28.6 \%)$ compared to PBMC HNSCC $(66.6 \pm 15.9 \% ; p<0.05$; Figure 1B, middle plot). Comparable percentages of $\mathrm{CD}^{+} \mathrm{T}$ cells were observed in PBMC HNSCC and PBMC HC $(66.6 \pm 15.9 \%$ vs. 69.3 $\pm 11.1 \%)$. The $\mathrm{CD} 4 / \mathrm{CD} 8$ ratio did not differ between all groups (Figure 1C).

Whereas naïve $\mathrm{T}$ cells $\left(\mathrm{CD} 45 \mathrm{RA}^{+} / \mathrm{CCR} 7^{+}\right)$ constituted $33.2 \pm 18.3 \%$ of $\mathrm{T}$ cells in the peripheral blood of healthy controls, their percentage in PBMC HNSCC was $22.4 \pm 14.6 \%$, in tumor samples $4.1 \pm 3.8 \%$ and in non-cancerous mucosa $7.7 \pm 7.2 \%$ (Figure 1D, left plot). The percentage in tumor samples was significantly decreased compared to PBMC HNSCC $(p<0.0001)$. Mucosa-associated T cells were predominantly antigenexperienced $\mathrm{CD} 45 \mathrm{RA}^{-} / \mathrm{CCR} 7^{-}$effector memory $\mathrm{T}$ cells with $68.6 \pm 12.3 \%$ of tumor-infiltrating T cells and 64.7 $\pm 8.2 \%$ of $\mathrm{T}$ cells in non-cancerous mucosa compared to significantly lower $39.9 \pm 13.9 \%$ in PBMC HNSCC $(p<0.0001$; Figure 1D, right plot). Percentages of effector memory T cells in PBMC of healthy donors and HNSCC patients were comparable $(30.8 \pm 9.3 \%$ vs. $39.9 \pm 13.9 \%)$.

To assess regulatory T cells, we analyzed the $\mathrm{CD}^{+} /$ $\mathrm{CD} 25^{+} / \mathrm{CD} 127^{\text {low }}$ and the $\mathrm{CD} 4^{+} / \mathrm{CD} 39^{+}$T-cell subset, which have been reported to contain a high percentage of $\mathrm{FoxP}^{+}$Treg [26-28]. CD4 ${ }^{+} / \mathrm{CD} 25^{+} / \mathrm{CD} 127^{\text {low }}$ Treg made up a significantly larger proportion of $\mathrm{T}$ cells in tumor samples $(10.3 \pm 6.3 \%)$ compared to PBMC HNSCC $(3.7 \pm 2.0 \% ; p<0.0001)$ and non-cancerous mucosa $(4.2 \pm 4.4 \%, p<0.05$; Figure 1E, left plot). The proportion of this regulatory T-cell phenotype was significantly increased in PBMC derived from HNSCC patients compared to healthy donors $(3.7 \pm 2.0 \%$ vs. 1.6 $\pm 0.7 \% ; p<0.005)$. Significant differences in the $\mathrm{CD}^{+} /$ $\mathrm{CD} 9^{+} \mathrm{T}$-cell population were detected in tumor tissue $(28.8 \pm 17.1 \%$ of T cells) compared to PBMC HNSCC (8.9 
$\pm 10.2 \%, p<0.0001)$, but not compared to non-cancerous mucosa $(19.7 \pm 18.4 \%)$. The difference between PBMC HNSCC and PBMC HC was statistically not significant $(8.9 \pm 10.2 \%$ vs. $4.2 \pm 3.1 \%, p=0.38$; Figure $1 \mathrm{E}$, right plot). The immunosuppressive microenvironment is also reflected by a low $\mathrm{CD} 8 /$ Treg ratio. $\left[\mathrm{CD}^{+}\right] /\left[\mathrm{CD}^{+} / \mathrm{CD}^{2} 5^{+} /\right.$ CD127 $7^{\text {low }}$ ratio was similarly decreased in tumor $(4.4 \pm$ $4.5)$ and mucosa $(4.0 \pm 2.7)$, being statistically significant between tumor samples and PBMC HNSCC (4.4 \pm 4.5 vs. $7.8 \pm 6.4 ; p<0.05)$. Comparison between PBMC $\mathrm{HNSCC}$ and $\mathrm{PBMC} \mathrm{HC}$ revealed a significant decrease of the $\left[\mathrm{CD}^{+}\right] /\left[\mathrm{CD}^{+} / \mathrm{CD} 25^{+} / \mathrm{CD} 127^{\text {low }}\right]$ ratio in PBMC of HNSCC patients (7.8 \pm 6.4 vs. $29.1 \pm 31.5$; $p<0.005$;
Figure 1F, left plot). However, [CD8 $\left.{ }^{+}\right] /\left[\mathrm{CD}^{+} / \mathrm{CD}^{2} 9^{+}\right]$ ratio only differed significantly between tumor tissue and PBMC HNSCC ( $1.4 \pm 1.5$ vs. $8.3 \pm 11.8 ; p<0.005$; Figure 1F, right plot).

\section{Digital analysis of $\mathrm{CD3}^{+}$and $\mathrm{CD8}^{+}$cells in $\mathrm{HNSCC}$ (immunohistochemistry) shows high concordance with flow-cytometric results and increased MHC I expression is associated with high T-cell infiltration}

Our customized digital image analysis protocol based on CellProfiler enabled us to perform quantification of $\mathrm{CD}^{+}$and $\mathrm{CD}^{+}$cells in entire cross sections of $\mathrm{HNSCC}$
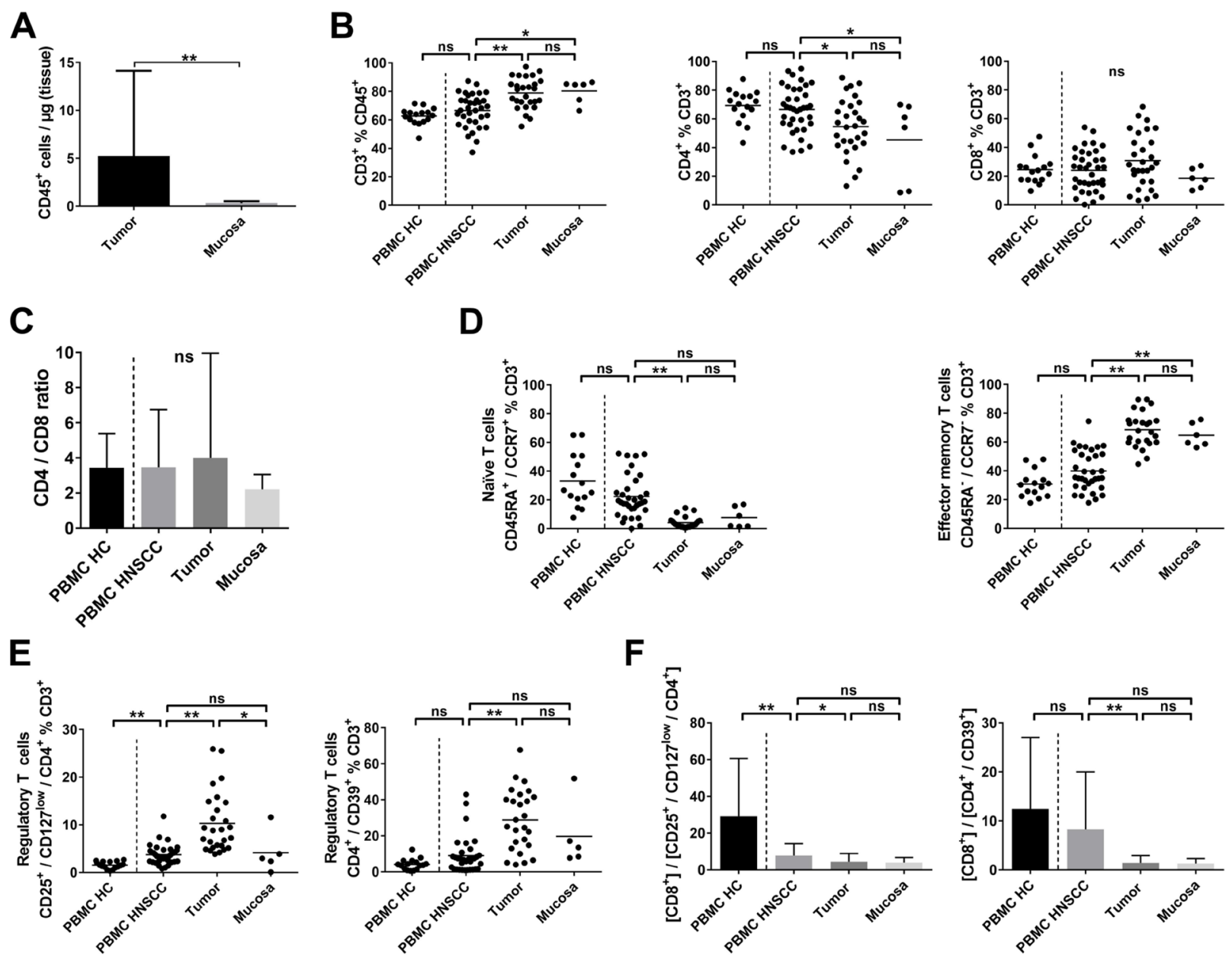

Figure 1: T-cell subsets in PBMC, tumor samples and non-cancerous mucosa of HNSCC patients and PBMC of healthy controls. Single cell suspensions of tumor tissue $(n=34)$, non-cancerous mucosa $(n=7)$, PBMCs of healthy controls (PBMC $\mathrm{HC}, n=15$ ) and PBMCs of patients with HNSCC (PBMC HNSCC, $n=34$ ) were analyzed by flow cytometry for their expression of T-cell related antigens. (A) Scatter plots showing the number of $\mathrm{CD}^{4} 5^{+}$cells per $\mu \mathrm{g}$ of tumor or mucosal tissue. (B) Scatter plots comparing the percentages of $\mathrm{CD}^{+} \mathrm{T}$ cells within the $\mathrm{CD}^{+} 5^{+}$fraction (left), $\mathrm{CD}^{+}$(middle plot) and $\mathrm{CD} 8^{+}$(right) cells within the $\mathrm{T}$ cells fraction. $(\mathbf{C}$ ) Depicted in bar graphs is the ratio of $\mathrm{CD}^{+}$and $\mathrm{CD}^{+} \mathrm{T}$ cells $\left(\mathrm{CD} 3^{+}\right.$fraction) in different compartments. (D) Comparison of the rate of naïve $\left(\mathrm{CD}^{2} 5 \mathrm{RA}^{+} / \mathrm{CCR}^{+}\right.$; left) and effector memory T cells $\left(\mathrm{CD} 45 \mathrm{RA}^{-} / \mathrm{CCR} 7^{-}\right.$; right) in the T-cell fraction, shown as scatter plots. (E) Percentages of regulatory T-cell phenotypes $\mathrm{CD} 4^{+} / \mathrm{CD} 25^{+} / \mathrm{CD} 127^{\text {low }}$ and $\mathrm{CD}^{+} / \mathrm{CD} 39^{+}$within $\mathrm{PBMC}$ of healthy donors, $\mathrm{HNSCC}$ patients, HNSCC tumor tissue and normal mucosa are compared in scatter plots. (F) Bar graphs comparing the ratio of CD8 $8^{+}$cells and regulatory T-cell phenotypes $\mathrm{CD}^{+} / \mathrm{CD} 25^{+} / \mathrm{CD} 127^{\text {low }}$ and $\mathrm{CD} 4^{+} / \mathrm{CD} 39^{+}$within the $\mathrm{CD}^{+}$fraction. For statistical analysis, Mann-Whitney test was used in (A), one-way ANOVA in (B) and right plot of (D) and Kruskal-Wallis test in (C), left plot of (D), (E) and (F). Data is depicted as mean \pm standard deviation. $* P<0.05 ; * * P<0.005 ;$ ns, not significant. 
tumors. Three different patterns of $\mathrm{CD}^{+}$and $\mathrm{CD}^{+}$cell infiltration could be discriminated: (1) high $\mathrm{CD} 3^{+}$and $\mathrm{CD} 8^{+}$ cell density in tumor core (CT) and invasive margin (IM), (2) high $\mathrm{CD}^{+}$and $\mathrm{CD}^{+}$cell density in IM and low density in $\mathrm{CT}$ and (3) low $\mathrm{CD}^{+}$and $\mathrm{CD}^{+}$cell density in $\mathrm{CT}$ and IM as shown by $\mathrm{CD} 3$ immunohistochemistry in three different exemplary HNSCC (Figure 2A). A schematic overview of the digital analysis process is depicted in Figure 2B. Results obtained by automated analysis were highly concordant with optical cell counting of selected slides. On average, an area of $5.4 \mathrm{~mm}^{2}$ (IM CD3), 25.6 $\mathrm{mm}^{2}$ (CT CD3), $5.0 \mathrm{~mm}^{2}$ (IM CD8) and $26.1 \mathrm{~mm}^{2}$ (CT CD8) was analyzed per section. Tumors with high $\mathrm{CD}^{+}$ and $\mathrm{CD}^{+}$cell infiltration classified as 'Immunoscore high' $(n=5)$ showed a mean $\mathrm{CD}^{+}$and $\mathrm{CD}^{+}$cell count of 551/ $\mathrm{mm}^{2} \pm 215 / \mathrm{mm}^{2}$ and $318 / \mathrm{mm}^{2} \pm 127 / \mathrm{mm}^{2}$, respectively, within the CT. $\mathrm{CD}^{+}$and $\mathrm{CD}^{+}$cell densities were significantly increased in the IM $\left(1117 / \mathrm{mm}^{2} \pm 188 / \mathrm{mm}^{2}\right.$ and $784 / \mathrm{mm}^{2} \pm 66 / \mathrm{mm}^{2}$, respectively) compared to the CT $(p<0.005)$. In contrast, $\mathrm{CD}^{+}$and $\mathrm{CD}^{+}$cell densities in the $\mathrm{CT}$ in tumors classified as $\mathrm{CD}^{+}$low and $\mathrm{CD}^{+}$low ('Immunoscore low'; $n=6$ ) was $173 / \mathrm{mm}^{2} \pm 160 / \mathrm{mm}^{2}$ and $50 / \mathrm{mm}^{2} \pm 22 / \mathrm{mm}^{2}$ compared to $621 / \mathrm{mm}^{2} \pm 327 / \mathrm{mm}^{2}$ and $247 / \mathrm{mm}^{2} \pm 151 / \mathrm{mm}^{2}$ in the IM, again showing higher CD3 ${ }^{+}$ and $\mathrm{CD}^{+}$cell infiltration in the IM than in the CT $(p<$ 0.05; Supplementary Figure 1). No HPV positive HNSCC was classified as 'Immunoscore low'.

We then compared tumor-infiltrating T-cell subsets determined by flow cytometry in 'Immunoscore high' and 'Immunoscore low' tumors. Compared to tumors which were classified as 'Immunoscore high' in immunohistochemical analyses, 'Immunoscore low' HNSCC tumors showed a significantly higher percentage of $\mathrm{CD}^{+} \mathrm{T}$ cells $(67.0 \pm 10.7 \%$ vs. $50.5 \pm 5.9 \%$; $p<$ $0.05)$ and significantly lower percentages of $\mathrm{CD}^{+} \mathrm{T}$ cells $(16.9 \pm 12.8 \%$ vs. $37.3 \pm 12.0 \% ; p<0.05$; Figure $2 \mathrm{C})$ in flow cytometry analyses. However, no differences were detected regarding the flow cytometrically determined percentage of effector memory $\mathrm{T}$ cells between 'Immunoscore low' and 'Immunoscore high' populations $\left(65.6 \pm 10.3 \%\right.$ vs. $63.4 \pm 8.1 \%$; Figure 2D). PD- $1^{+} \mathrm{T}$ cells were not significantly increased in 'Immunoscore high' compared to 'Immunoscore low' tumors (62.4 $\pm 13.7 \%$ vs. $53.3 \pm 7.6 \% ; p=0.31)$, while CTLA- $4^{+} \mathrm{T}$ cells were significantly decreased $(7.5 \pm 6.3 \%$ and 18.4 $\pm 2.0 \%$, respectively; $p<0.05$; Figure $2 \mathrm{E}$ ). Regulatory T-cell populations $\left(\mathrm{CD}^{+} / \mathrm{CD} 9^{+}\right.$; $\left.\mathrm{CD}^{+} / \mathrm{CD} 25^{+} / \mathrm{CD} 127^{\text {low }}\right)$ showed similar percentages in both groups (data not shown).

It has been shown in non-small cell lung cancer that high intratumoral T-cell infiltration occurs mainly in tumors with high expression levels of MHC class I on tumor cells [21]. We therefore examined MHC class I expression in HNSCC previously classified as 'Immunoscore high' and 'Immunoscore low'. As it is known that in HPV 16 positive cancer cells viral oncoprotein E7 leads to a decreased MHC class I expression via transcriptional regulation [29], only HPV negative HNSCC were included. Different patterns of MHC I expression on tumor cells could be observed. An exemplary picture of a HNSCC tumor with low expression of MHC I on tumor cells, but high expression on surrounding and infiltrating immune cells is shown on the left, an example of high MHC I expression on tumor cells is shown on the right side of Figure 2F. 'Immunoscore low' HNSCC demonstrated low levels of MHC class I expression in $6 / 6$ cases, whereas only $1 / 4$ cases of 'Immunoscore high' tumors showed low and 3/4 cases high MHC I expression. The probability for high MHC I expression in tumor cells was significantly increased in the 'Immunoscore high' compared to the 'Immunoscore low' group ( $p<0.05$; Figure 2G). MHC I expression in HPV positive HNSCC was low in $4 / 5$ cases (data not shown).

\section{PD-1, PD-L1 and CTLA-4 are highly expressed on $T$ cells in HNSCC tumor tissue}

In view of the increasing use of immune checkpoint inhibitors, we examined expression of PD-1, PD-L1 and CTLA-4 on T cells. HNSCC tumor tissue samples contained a significantly increased fraction of PD-1 expressing $\mathrm{T}$ cells $(55.7 \pm 19.0 \%)$ compared to PBMC HNSCC $(18.0 \pm 11.2 \% ; p<0.0001)$, but not compared to non-cancerous mucosa $(32.6 \pm 22.2 \%)$. An increased proportion of $\mathrm{PD}-1^{+} \mathrm{T}$ cells was observed in PBMC HNSCC compared to PBMC HC $(18.0 \pm 11.2 \%$ vs. $6.4 \pm$ $2.5 \% ; p<0.005)$. PD $-1^{+} \mathrm{T}$ cells were mainly $\mathrm{CD} 4^{+}$, with $77.0 \pm 7.5 \%$ in PBMC HC not significantly more frequent than in PBMC HNSCC $(68.0 \pm 12.2 \%)$. Percentages in non-cancerous mucosa were reduced compared to PBMC HNSCC (43.3 $\pm 25.1 \%$ vs. $68.0 \pm 12.2 \% ; p<0.005)$. The difference between PBMC HNSCC and tumor tissue $(59.3 \pm 17.3 \%)$ was statistically not significant $(p=0.13)$. Percentages of $\mathrm{CD}^{+}$cytotoxic T cells in the PD $-1^{+}$fraction were comparably low in PBMC HNSCC (23.9 $\pm 10.9 \%)$, tumor tissue $(27.8 \pm 17.3 \%)$, non-cancerous mucosa $(22.0$ $\pm 7.2 \%)$ and PBMC HC (18.7 $\pm 6.7 \%$; Figure $3 \mathrm{~A})$.

PD-L1 expression was significantly increased in the T-cell fraction of PBMC HNSCC $(39.2 \pm 19.9 \%)$ compared to PBMC HC $(21.3 \pm 12.6 \% ; p<0.05)$. PBMC HNSCC, tumor tissue $(44.0 \pm 15.9 \%)$ and non-cancerous mucosa $(35.5 \pm 14.0 \%)$ showed comparable percentages of PD-L1 expression within the T-cell fraction. Whereas in PBMC $\mathrm{HC}, \mathrm{CD}^{+} \mathrm{T}$ cells made up only a small fraction of PD-L $1^{+} \mathrm{T}$ cells $(7.1 \pm 10.3 \%)$, the percentage highly increased in PBMC HNSCC (42.8 $\pm 24.4 \% ; p<0.0001)$. Non-cancerous mucosa $(14.2 \pm 15.1 \%)$ and tumor tissue $(21.9 \pm 12.4 \%)$ showed similar percentages of $\mathrm{CD}^{+} \mathrm{T}$ cells in the PD-L1 ${ }^{+}$fraction. The vast majority of PD$\mathrm{L}^{+} \mathrm{T}$ cells in PBMC HC were cytotoxic T cells $(89.8 \pm$ $10.5 \%$ ), with significantly lower percentages in PBMC HNSCC $(51.1 \pm 23.7 \% ; p<0.0001)$. Again, similar 
A

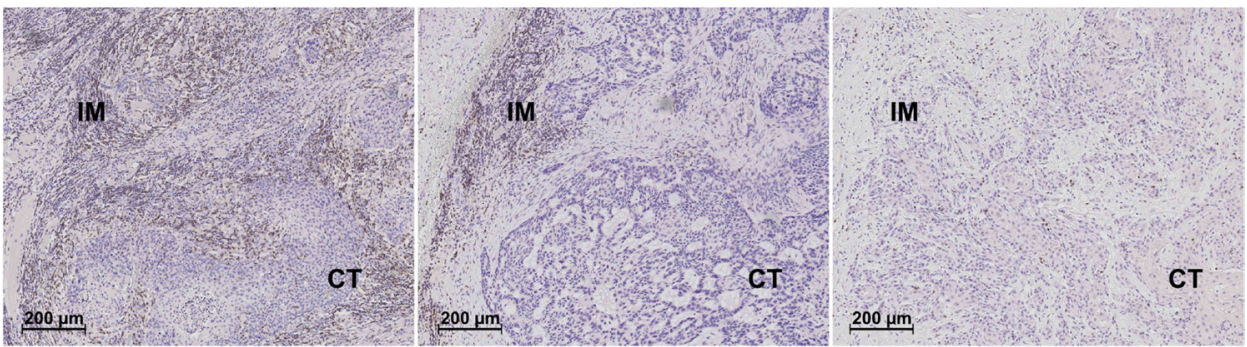

B

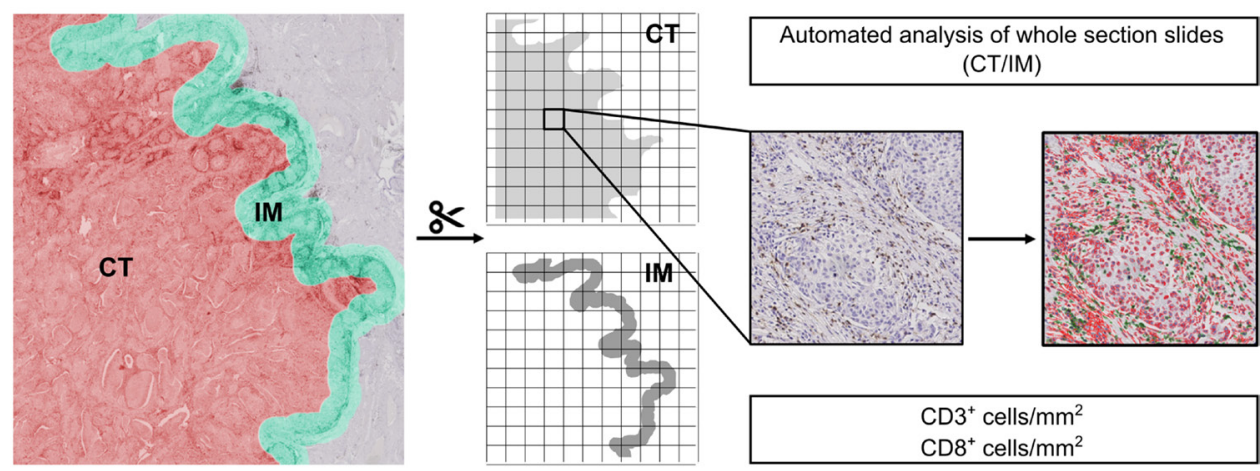

C

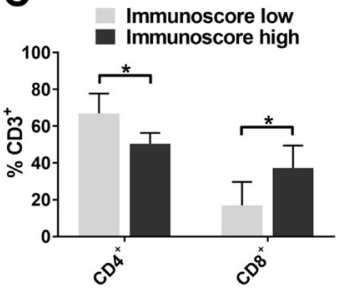

$\mathbf{F}$

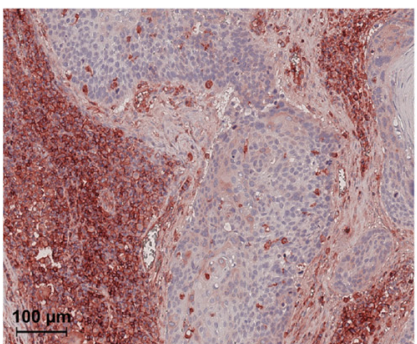

D
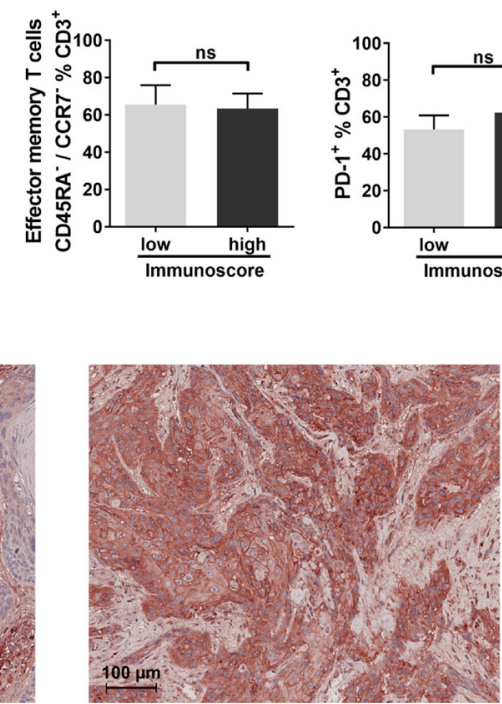

E
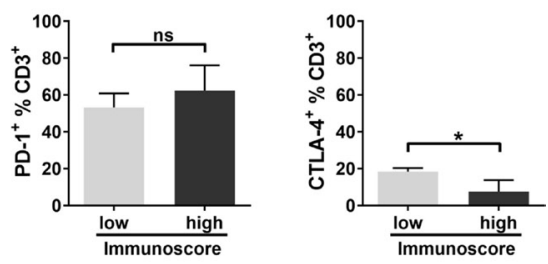

G

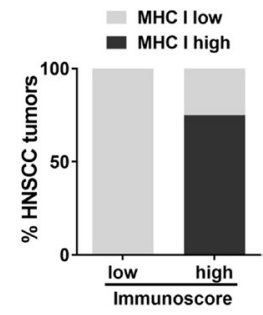

Figure 2: Digital analysis of $\mathrm{CD3}^{+}$and $\mathrm{CD8}^{+}$cells in cross sections of entire $\mathrm{HNSCC}$ tumors and comparison with results obtained by flow cytometry. (A) Exemplary immunohistochemical staining of CD3 showing three different T-cell infiltration patterns in tumor core (CT) and invasive margin (IM) of HNSCC: (1) high $\mathrm{CD}^{+}$and CD8 $8^{+}$cell infiltration of IM and CT, (2) high TIL density in the IM and (3) low $\mathrm{CD}^{+}$and $\mathrm{CD} 8^{+}$infiltration in $\mathrm{CT}$ and IM. (B) Analysis process of immunohistochemical stainings of entire HNSCC tumor cross sections: cross sections of HNSCC stained for CD3 and CD8 are subjected to automated analysis of IM and CT. IM (area ranging from $50 \mu \mathrm{m}$ within the tumor to $300 \mu \mathrm{m}$ outside the tumor border; green area) and CT (whole tumor section excluding first $50 \mu \mathrm{m}$ adjacent to the tumor border; red area) are schematically shown on the left side. Both areas are subsequently separated and cropped into tiles suitable for automated analysis of DAB-stained cells. Shown on the right side is an exemplary tile derived from the CT stained for $\mathrm{CD} 3$ before and after analysis (positive cells are displayed in green, nuclei in red). As a result, $\mathrm{CD}^{+}$and $\mathrm{CD}^{+}$cell count per $\mathrm{mm}^{2}$ is calculated for the whole area of IM and CT, respectively. (C) Bar graphs showing flow-cytometrically determined percentages of $\mathrm{CD}^{+}$ and CD8 ${ }^{+} \mathrm{T}$ cells in 'Immunoscore low' and 'Immunoscore high' HNSCC. (D) Comparison of percentages of effector memory T cells in 'Immunoscore low' and 'Immunoscore high' tumors. (E) PD-1 (left) and CTLA-4 (right) expression on T cells compared in 'Immunoscore low' and 'Immunoscore high' HNSCC. (F) Examples of low (left) and high (right) MHC class I expression of HNSCC tumor cells in immunohistochemical stainings. (G) Stacked columns showing percentages of high and low MHC class I expression in HPV negative HNSCC classified as 'Immunoscore low' $(n=6)$ and 'Immunoscore high' $(n=4)$. The probability for high MHC I expression in tumor cells is significantly higher in the 'Immunoscore high' than the 'Immunoscore low' group $(p<0.05$; Fisher's exact test). In (C) - (E), Student's $t$ test was performed ('Immunoscore high', $n=5$; 'Immunoscore low', $n=6$ ). Data is depicted as mean \pm standard deviation. ${ }^{*} P<0.05$; ns, not significant. 
percentages of $\mathrm{PD}-\mathrm{L} 1^{+}$cells were $\mathrm{CD} 8^{+}$in tumor tissue $(69.6 \pm 14.7 \%)$ and non-cancerous mucosa $(78.5 \pm 18.6 \%$; Figure 3B).

CTLA $-4^{+} \mathrm{T}$ cells were substantially less frequent than $\mathrm{PD}-1^{+}$and PD-L1 ${ }^{+} \mathrm{T}$ cells. Almost no CTLA-4 expressing T cells were observed in PBMC HC $(0.2 \pm$ $0.1 \%$ ), which was significantly lower than the percentage detected in PBMC HNSCC $(2.0 \pm 2.1 \%, p<0.005)$. However, the percentage of CTLA $-4^{+} \mathrm{T}$ cells increased significantly in HNSCC tumor microenvironment (10.0 \pm $7.5 \% ; p<0.0001)$. The percentage of CTLA $-4^{+} \mathrm{T}$ cells in tumor tissue and non-cancerous mucosa $(5.1 \pm 3.3 \%)$ did not differ significantly. CD4 ${ }^{+} \mathrm{T}$ cells in PBMC $\mathrm{HC}$ made up a significantly lower proportion of CTLA $-4^{+} \mathrm{T}$ cells $(24.8 \pm 10.7 \%)$ than in PBMC HNSCC $(69.3 \pm 14.6 \% ; p$ $<0.0001)$, whereas percentages in PBMC HNSCC and tumor tissue $(61.4 \pm 16.3 \%)$ were comparably high. The proportion of $\mathrm{CD}^{+}$cells among CTLA- $4^{+} \mathrm{T}$ cells in noncancerous mucosa was decreased compared to PBMC HNSCC $(51.0 \pm 18.8 \%$ vs. $69.3 \pm 14.6 \% ; p<0.05)$, but not compared to tumor tissue. The majority of CTLA$4^{+} \mathrm{T}$ cells was $\mathrm{CD} 8^{+}$in PBMC HC $(55.9 \pm 19.1 \%)$, with significantly lower percentages of $\mathrm{CD} 8^{+} \mathrm{T}$ cells in the CTLA- $4^{+}$T-cell subset in PBMC HNSCC (18.2 $\pm 11.4 \%$; $p<0.0001)$. Percentages in PBMC HNSCC, tumor tissue $(20.9 \pm 10.9 \%)$ and non-cancerous mucosa $(21.2 \pm 16.1 \%)$ were comparable (Figure 3C).

\section{HPV positive tumors show a higher number of tumor-infiltrating $T$ cells, but a similar distribution of T-cell subsets compared to HPV negative tumors}

In HPV positive tumors, a higher number of CD45 $5^{+}$lymphocytes $(13.2 \pm 13.9$ cells $/ \mu \mathrm{g})$ than in HPV negative tumors $(3.2 \pm 5.6$ cells $/ \mu \mathrm{g} ; p<0.05)$ and in non-cancerous mucosa $(0.3 \pm 0.2$ cells $/ \mu \mathrm{g} ; p<0.0001)$ was detected (Figure 4A). Comparable results were obtained when analyzing oropharyngeal squamous cell carcinoma only (data not shown). We did not find any significant differences in the rate of $\mathrm{CD} 4^{+}$or $\mathrm{CD} 8^{+} \mathrm{T}$ cells related to the HPV status (Figure 4B). The proportion of effector memory $\mathrm{T}$ cells was similarly high in the tumor microenvironment of HPV positive and HPV negative patients $(66.5 \pm 12.7 \%$ and $70.2 \pm 12.2 \%$; Figure 4C). There was a statistically not significant trend towards higher numbers of regulatory $\mathrm{T}$ cells in the microenvironment of HPV negative tumors compared to $\mathrm{HPV}$ positive tumors. $\mathrm{CD} 4^{+} / \mathrm{CD} 25^{+} / \mathrm{CD} 127^{\text {low }}$ cells accounted for $11.5 \pm 7.0 \%$ of T cells in HPV negative tumors and $8.1 \pm 5.3 \%$ in HPV positive tumors ( $p=0.24$; Figure 4D, left plot). Similar results were obtained for the $\mathrm{CD}^{+} / \mathrm{CD} 9^{+}$phenotype $(28.8 \pm 20.9 \%$ vs. $23.8 \pm 7.8 \%$; $p=0.52$; Figure $4 \mathrm{D}$, right plot).

Analyzing immune checkpoint expression of tumorinfiltrating $\mathrm{T}$ cells depending on HPV status revealed no significant differences between HPV negative and HPV positive tumors (Figure 4E, left plot). However, a trend towards higher percentages of $\mathrm{PD}-1^{+} \mathrm{T}$ cells in the microenvironment of HPV positive HNSCC was observed compared to HPV negative tumors ( $48.4 \pm 18.1 \%$ vs. 61.2 $\pm 14.1 \% ; p=0.12$ ), due to significantly higher percentages of PD-1 expressing cytotoxic $\mathrm{CD} 8^{+} \mathrm{T}$ cells $(75.4 \pm 9.4 \%$ vs. $51.2 \pm 24.6 \%, p<0.05$; Figure $4 \mathrm{E}$, middle plot). No difference in PD- 1 expression in $\mathrm{CD}^{+}$cells between HPV positive and HPV negative HNSCC $(55.0 \pm 16.4 \%$ vs. $49.1 \pm 19.0 \%$ ) was observed (Figure 4E, middle plot). A statistically not significant trend towards decreased proportions of CTLA-4 expressing T cells was observed in HPV positive HNSCC $(6.6 \pm 5.2 \%$ vs. $11.6 \pm 8.5 \%$; $p=0.17$, which was similarly present in $\mathrm{CD} 4^{+}$and $\mathrm{CD} 8^{+}$ $\mathrm{T}$ cells of HPV positive and HPV negative tumors (14.6 $\pm 11.6 \%$ vs. $9.9 \pm 8.5 \% ; p=0.36 ; 8.3 \pm 8.6 \%$ vs. $5.5 \pm$ $4.2 \% ; p=0.44$; Figure $4 \mathrm{E}$, right plot).

\section{Regulatory $\mathrm{T}$ cells $\left(\mathrm{CD}^{+} / \mathrm{CD}^{+} 5^{+} / \mathrm{CD} 127^{\text {low }}\right)$ and the percentage of $\mathrm{CTLA}-4^{+} \mathrm{T}$ cells are increased in the tumor microenvironment of early stage HNSCC}

Patients with late stage HNSCC (UICC stage III/ IV) demonstrated a slightly increased CD4/CD8 ratio compared to early stage tumors in PBMC and tumor microenvironment $(3.9 \pm 3.7$ vs. $2.5 \pm 1.9 ; 4.4 \pm 6.6$ vs. $2.7 \pm 3.5$, respectively). However, mean values were not significantly different $(p=0.23 ; p=0.51$, respectively; Figure 5A). The majority of $\mathrm{T}$ cells within the tumor showed an effector memory phenotype irrespective of stage category $(63.8 \pm 13.1 \%$ vs. $70.9 \pm 11.5 \%$; Figure $5 \mathrm{~B}$, left plot). T cells with the regulatory phenotype $\mathrm{CD}^{+} /$ $\mathrm{CD} 25^{+} / \mathrm{CD} 127^{\text {low }}$ showed a higher percentage in the microenvironment of early stage HNSCC $(14.4 \pm 6.5 \%)$ compared to late stage HNSCC $(8.9 \pm 5.7 \% ; p<0.05$; Figure 5B, middle plot). Percentages of $\mathrm{T}$ cells with the regulatory phenotype $\mathrm{CD} 4^{+} / \mathrm{CD} 39^{+}$were similarly high $(29.4 \pm 16.3 \%$ vs. $28.6 \pm 17.8 \%$; Figure 5B, right plot).

No significant differences were observed regarding PD-1 and PD-L1 expression of tumor-infiltrating T cells related to disease stage $(49.9 \pm 20.8 \%$ vs. $57.9 \pm 18.3 \%$; $p=0.35$ and $53.1 \pm 12.9 \%$ vs. $41.2 \pm 15.9 \% ; p=0.11$. However, CTLA $-4^{+}$T cells were significantly decreased in the microenvironment of late stage HNSCC compared to early stage $(18.9 \pm 11.3 \%$ vs. $8.2 \pm 5.2 \% ; p<0.05$; Figure 5C), which was attributable to lower percentages of CTLA- 4 expressing CD4 ${ }^{+} \mathrm{T}$ cells $(10.6 \pm 6.2 \%$ vs. $26.1 \pm 17.2 \% ; p<0.05)$, but not to altered expression of CTLA-4 in $\mathrm{CD}^{+} \mathrm{T}$ cells $(6.5 \pm 6.7 \%$ vs. $12.2 \pm 7.5 \%$; $p=0.14$; Figure 5D, right plot). PD-1 expression in the $\mathrm{CD}^{+}$and $\mathrm{CD}^{+}{ }^{+}$-cell subsets in HNSCC tumors was not significantly different comparing early and late stage (52.3 $\pm 20.3 \%$ vs. $55.1 \pm 19.6 \%$ and $50.6 \pm 25.0 \%$ vs. $65.3 \pm$ $22.7 \%$; Figure 5D, left plot). This was also the case for 
PD-L1 expression of tumor-infiltrating $\mathrm{CD}^{+}$and $\mathrm{CD}^{+} \mathrm{T}$ cells $(26.5 \pm 19.4 \%$ vs. $17.0 \pm 12.6 \%$ and $89.4 \pm 21.4 \%$ vs. $91.1 \pm 12.5 \%$, Figure 5D, middle plot).

\section{DISCUSSION}

In this study, we provide the first comprehensive analysis of multiple T-cell subsets and the expression of different and clinically relevant immune checkpoint molecules on T cells in treatment-naïve HNSCC, noncancerous mucosa and peripheral blood of patients and healthy donors. Previous studies investigating TILs and immune checkpoint molecules in HNSCC were mainly based on immunohistochemistry data [30-32]. Furthermore, our study combines the results of immunohistochemistry and flow cytometry. We found a significantly higher number of effector memory $\mathrm{T}$ cells and Treg in the tumor microenvironment compared
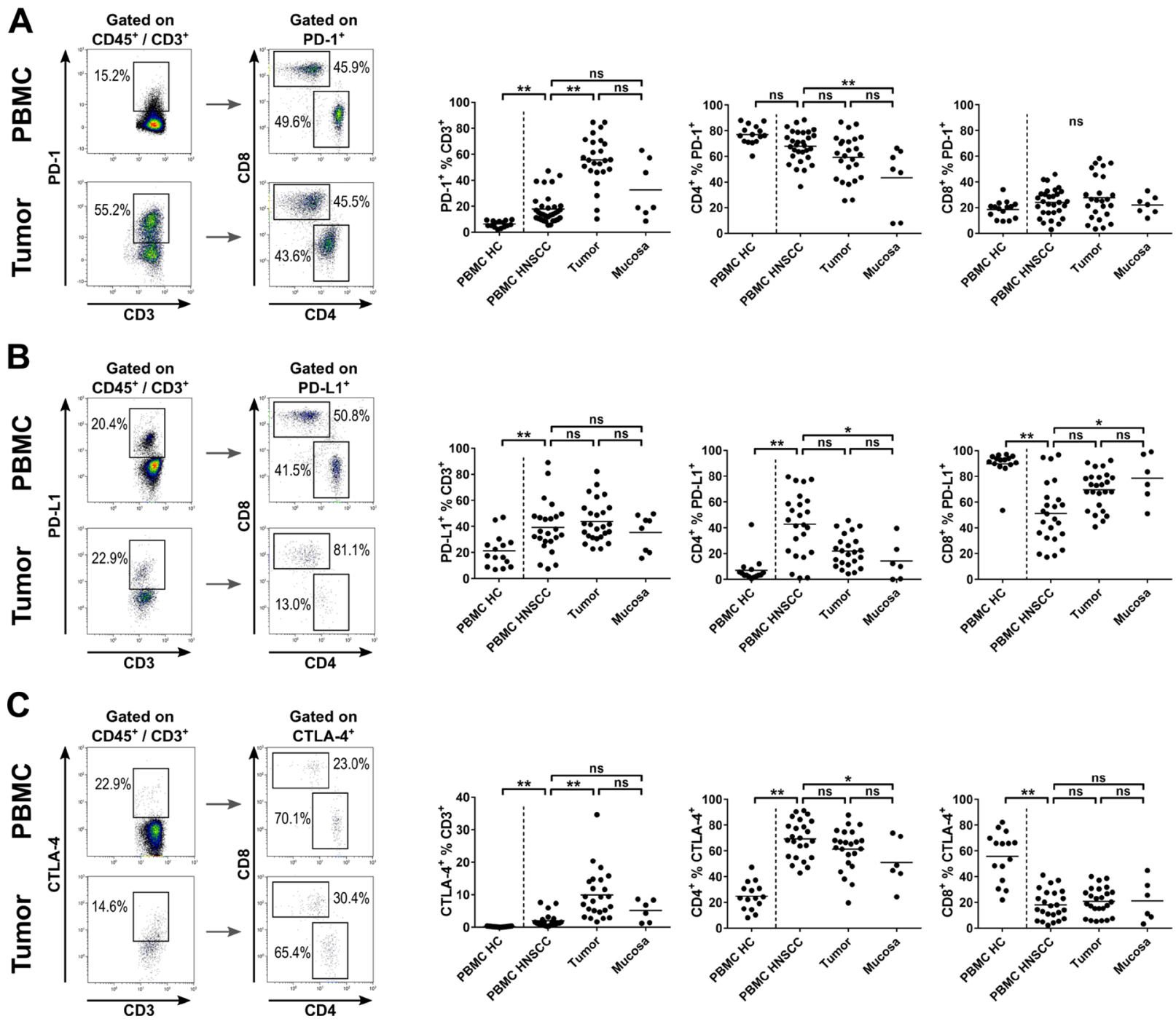

Figure 3: Expression of immune checkpoint molecules on T cells in HNSCC patients. T-cell subsets in PBMCs of healthy controls (PBMC HC, $n=15$ ), PBMCs of HNSCC patients (PBMC HNSCC, $n=32$ ), single cell suspensions of tumor tissue $(n=31$ ) and non-cancerous mucosa $(n=7)$ were analyzed by flow cytometry for immune checkpoint molecule expression. (A) Exemplary flow cytometry analysis of PD-1 expression in PBMC and tumor tissue of HNSCC. PD-1 expressing T cells were subcategorized according to their membranous CD4 and CD8 expression, as shown in dot plot graphs on the left side. Scatter plots comparing the percentage of PD-1 expressing cells within the T-cell fraction in PBMC HC, PBMC HNSCC, tumor tissue and mucosa (middle). The two scatter plot graphs on the right side show the percentage of $\mathrm{CD}^{+}$and $\mathrm{CD}^{+} \mathrm{T}$ cells within the PD-1 ${ }^{+} \mathrm{T}$-cell fraction. (B) Similar to (A), exemplary dot plots of PD-L1 expressing T-cell subsets are depicted on the left side. Percentages of PD-L1 expressing T cells and CD4 ${ }^{+}$and CD8 ${ }^{+}$PD-L1 ${ }^{+} \mathrm{T}-\mathrm{cell}$ subsets are shown in scatter plots on the right side (comparing PBMC HC, PBMC HNSCC, tumor tissue and mucosa in each graph). (C) Similar to (A), gating of CTLA-4 ${ }^{+}$T cells and subsets $\left(C D 4^{+}\right.$and $\left.C D 8^{+}\right)$is shown on the left side. The percentage of CTLA-4 expressing T cells and $\mathrm{CD}^{+}$and $\mathrm{CD} 8^{+}$subsets within this fraction are depicted in scatter plots on the right side. For statistical analysis, one-way ANOVA was used in middle and right plot of $(\mathrm{A})$ and $(\mathrm{C})$ and left plot of (B). Kruskal-Wallis test was used for all remaining analyses. The mean of every dataset is depicted. $* P<0.05 ; * * P<0.005$; ns, not significant. 
to PBMC. Moreover, we could demonstrate that expression of the immune checkpoint molecules CTLA4, PD-1 and PD-L1 was increased on intratumoral and circulating $\mathrm{T}$ cells in HNSCC patients compared to healthy donors, reflecting an immunosuppressive tumor microenvironment.
The lymphocytic infiltrate of tumors is known to have an impact on the prognosis of malignant disease [33-35]. In HNSCC, a high density of TILs is associated with improved patient outcome [36, 37]. PBMC of HNSCC patients were shown to consist of a significantly lower number of naïve $\mathrm{CD}^{+} / \mathrm{CD} 45 \mathrm{RO}^{-} /$

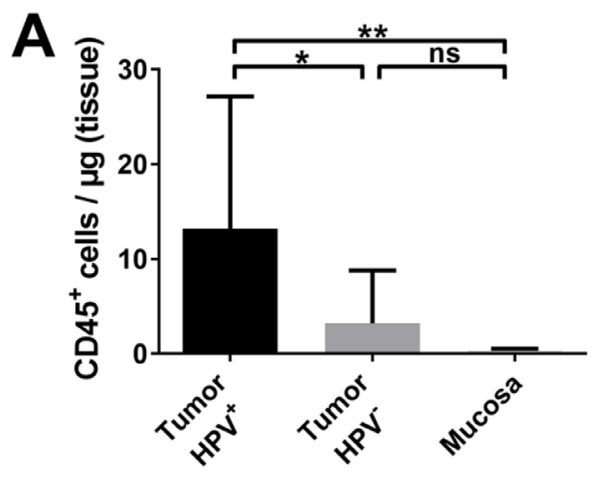

B
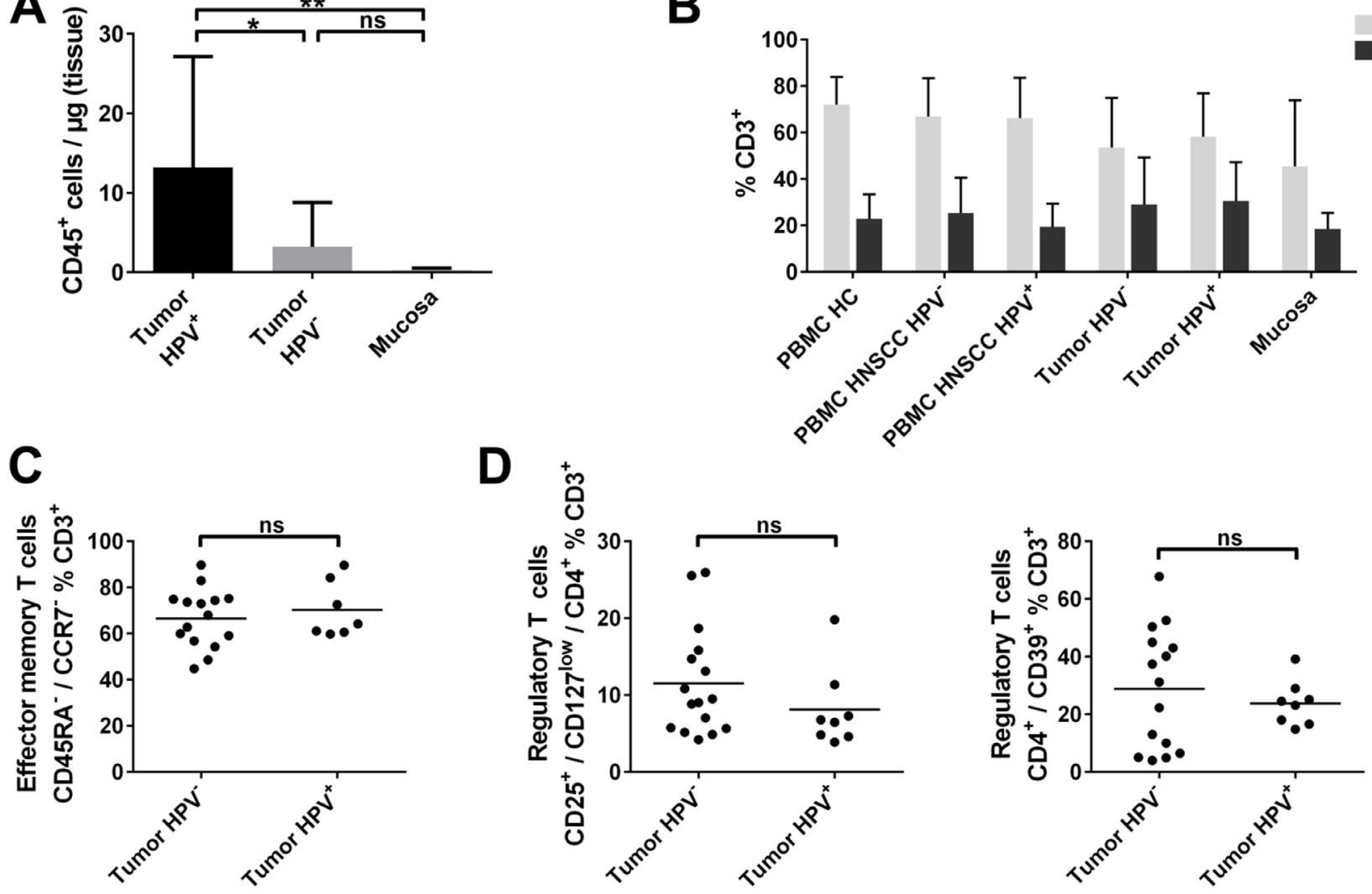

$\mathbf{E}$
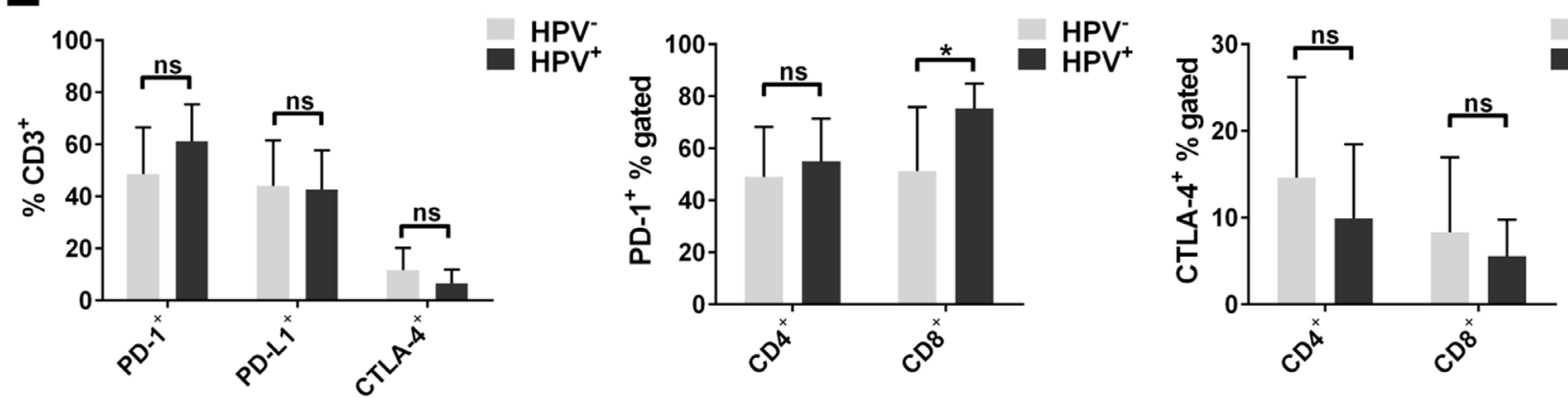

Figure 4: Lymphocyte infiltration and T-cell subsets in HPV positive and HPV negative HNSCC. (A) Flow-cytometric analysis of $\mathrm{CD}^{+} 5^{+}$cells per $\mu \mathrm{g}$ tissue in HPV positive HNSCC tumors $(n=8)$, HPV negative HNSCC $(n=26)$ and non-cancerous mucosa of the same patients $(n=7)$. (B) Percentages of $\mathrm{CD}^{+}$and $\mathrm{CD}^{+}$cell subsets within the $\mathrm{CD} 3^{+} \mathrm{T}$ cells compared in PBMC of healthy donors, PBMC and tumor tissue of HPV negative and HPV positive HNSCC patients and non-cancerous mucosa. (C) Effector memory T-cell subsets (CD45RA $/ \mathrm{CCR}^{-}$) are compared in tumor tissue of HPV positive and negative HNSCC. (D) Comparison of percentages of different regulatory T-cell phenotypes $\mathrm{CD}^{+} / \mathrm{CD} 25^{+} / \mathrm{CD} 127^{\text {low }}$ and $\mathrm{CD} 4^{+} / \mathrm{CD} 39^{+}$in $\mathrm{HPV}$ positive and negative $\mathrm{HNSCC}$ tumor tissue. (E) Overview of checkpoint molecule expressing T cells (PD-1, PD-L1 and CTLA-4) in the tumor microenvironment of HPV positive and negative HNSCC (left plot); percentages of PD- $1^{+}$and CTLA- $4^{+}$T cells in the CD4 ${ }^{+}$and $\mathrm{CD} 8^{+}$T-cell fraction of HPV positive and negative HNSCC tumor tissue (middle and right plot). Kruskal-Wallis test was used in (A) and $t$ tests were performed in (C), (D) and (E). Data is depicted as mean \pm standard deviation. $* P<0.05 ; * * P<0.0001$; ns, not significant. 
$\mathrm{CD} 27^{+} \mathrm{T}$ cells and an increased pool of memory $\mathrm{CD}^{+} /$ $\mathrm{CD}^{2} 5 \mathrm{RO}^{+} \mathrm{T}$ cells compared to healthy controls [38]. In line with these results, we found a decreased rate of naïve $\mathrm{T}$ cells $\left(\mathrm{CD} 45 \mathrm{RA}^{+} / \mathrm{CCR}^{+}\right)$and an increased frequency of effector memory $\mathrm{T}$ cells $\left(\mathrm{CD} 45 \mathrm{RA}^{-} / \mathrm{CCR} 7^{-}\right)$ in the tumor microenvironment compared to $\mathrm{PBMC}$ of cancer patients. However, the memory phenotype of $\mathrm{T}$ cells was also detected in non-cancerous mucosa. These findings could reflect changes in T-cell phenotypes while moving from peripheral blood into the tissue and the immunosuppressive microenvironment even in morphologically non-cancerous tissue.

Treg are increased in peripheral blood and tumor sites of patients with solid tumors including HNSCC $[16,39,40]$, which contributes to the suppression of an effective antitumor immune response. Our results support previous findings by showing an increased rate of Treg (either $\mathrm{CD}^{+} / \mathrm{CD} 25^{+} / \mathrm{CD} 127^{\text {low }}$ or $\mathrm{CD}^{+} /$ $\mathrm{CD}^{3} 9^{+}$) in TILs compared to non-cancerous mucosa and PBMC of tumor patients. Furthermore, the fraction of $\mathrm{CD}^{+} / \mathrm{CD} 25^{+} / \mathrm{CD} 127^{\text {low }}$ Treg was increased in PBMC of patients compared to healthy controls, suggesting a systemic immunosuppressive activity in HNSCC patients. Surprisingly, the same Treg phenotype was elevated in the microenvironment of low stage HNSCC compared to advanced stage. This potentially reflects a reduction of tumor-induced inflammation in early disease mediated by Treg [41].

Immune checkpoint molecules including CTLA-4, PD-1 and PD-L1 are key molecules involved in maturation and suppressive functions of tumor-infiltrating $\mathrm{T}$ cells [23, 24]. Immune checkpoint molecules are characteristic of exhausted T cells [42], which develop after long-term exposure to antigens [43]. In consequence, exhausted $\mathrm{T}$ cells are incapable of robust effector responses upon antigen exposure $[44,45]$. However, they can be reactivated using immune-checkpoint blockade [46] In $\mathrm{HNSCC}, \mathrm{PD}-1^{+} \mathrm{T}$ cells were found to be increased and associated with an improved prognosis in the setting of HPV positivity [40, 47, 48]. In a recent study evaluating PD-L1 expression by immunohistochemistry in oral squamous cell carcinoma, high PD-L1 levels were associated with metastasis and poor prognosis [49]. PD1-pathway blockade in tumors lacking PD-L1 expression on tumor cells resulted in clinical response in different entities including HNSCC $[25,50,51]$. This phenomenon can be explained by expression of PD-1 or PD-L1 on non-malignant cells in the tumor microenvironment. Expression of immune checkpoints on primary tumor cells has been analyzed in different cancer entities. However, their expression on TILs is widely unknown. Our study represents the first comprehensive analysis of
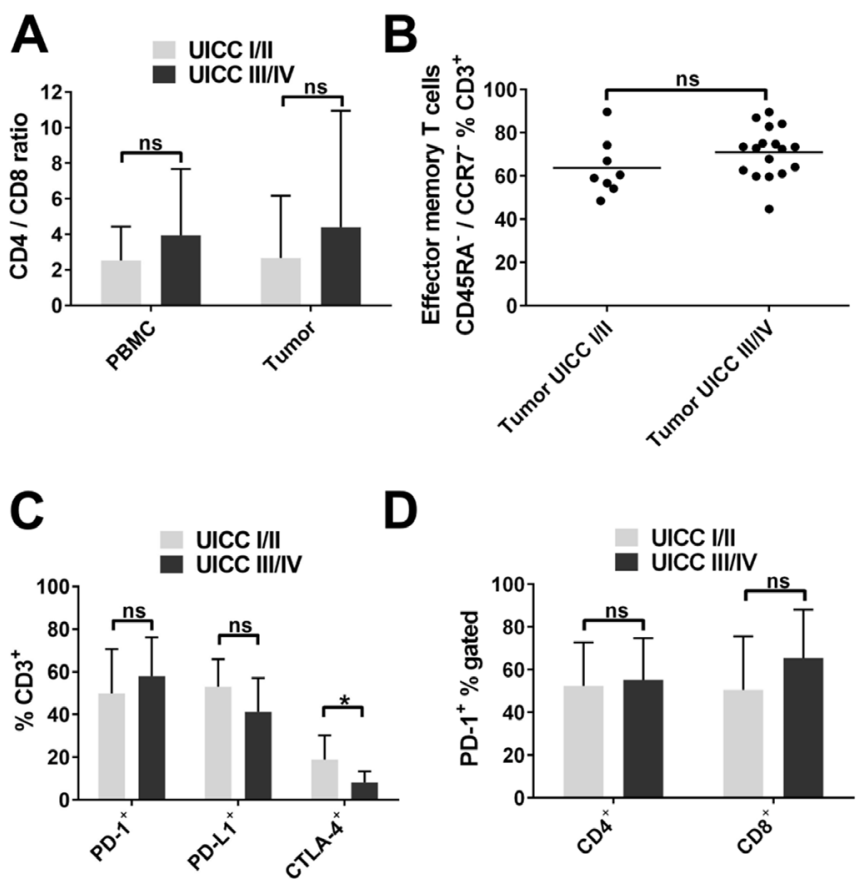
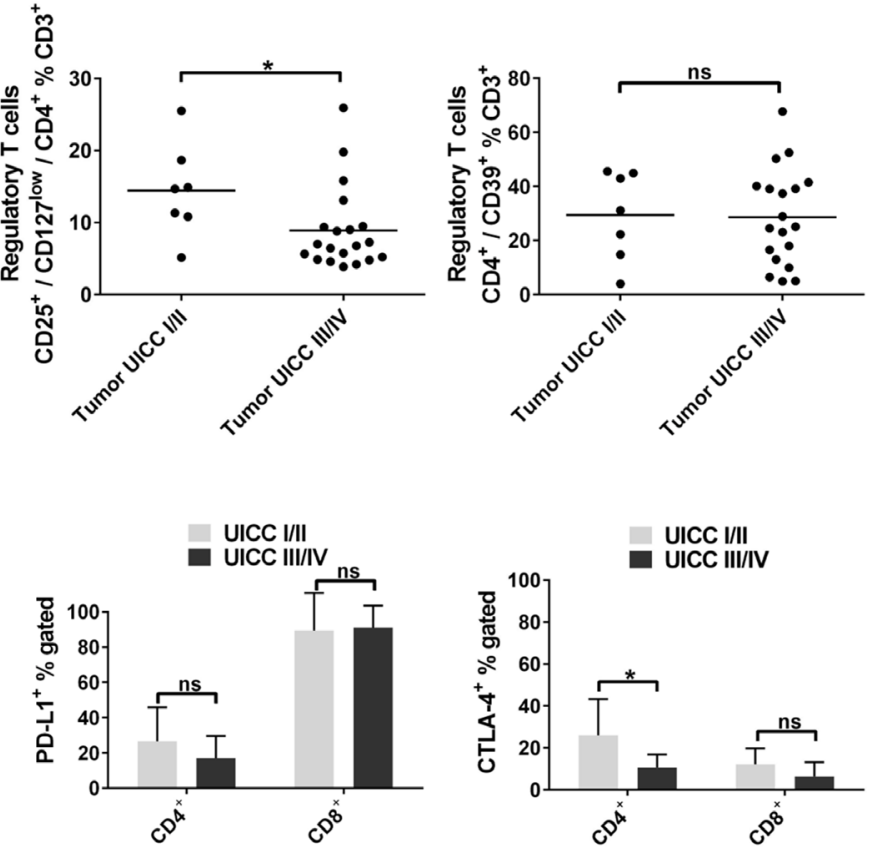

Figure 5: T-cell subsets in early and late stage HNSCC. (A) CD4/CD8 ratio in PBMC and tumor tissue of HNSCC patients according to UICC tumor stage (stage I/II vs. III/IV). (B) Scatter plots showing effector memory T cells $\left(\mathrm{CD}^{4} 5 \mathrm{RA}^{-} / \mathrm{CCR}^{-}\right.$; left) and regulatory T-cell phenotypes $\left(\mathrm{CD}^{+} / \mathrm{CD} 25^{+} / \mathrm{CD} 127^{\text {low }}\right.$; middle; $\mathrm{CD}^{+} / \mathrm{CD} 39^{+}$; right) in the tumor microenvironment of early (UICC I/II) and late (UICC III/IV) stage HNSCC. (C) Overview of checkpoint molecule expression (PD-1, PD-L1, CTLA-4) in tumor-infiltrating T cells in early and late stage HNSCC. (D) Comparison of percentages of PD-1 ${ }^{+}$(left), PD-L1 ${ }^{+}$(middle) and CTLA-4 ${ }^{+}$(right) cells in CD4 ${ }^{+}$and $\mathrm{CD}^{+}$T-cell subsets of early and late stage HNSCC tumors. PBMC and tumor UICC I/II, $n=11$; PBMC and tumor UICC III/IV, $n=23$; for statistical analysis, $t$ tests were performed in (A) - (D), except for comparison of CTLA- $4^{+}$T cells in (C) and CTLA- ${ }^{+\%}$ CD $4^{+}$in (D). Mann-Whitney test was used in these cases. Data is depicted as mean \pm standard deviation. $* P<0.05$; ns, not significant. 
immune checkpoint expression on tumor-infiltrating T-cell subsets in HNSCC, non-cancerous mucosa and peripheral blood from patients and healthy donors. We detected a significantly higher rate of PD-1 and CTLA-4 expression on TILs compared to PBMC of cancer patients with highly variable expression profiles on $\mathrm{CD}^{+}$and $\mathrm{CD}^{+}$cells. Strikingly, the percentage of PD-1, PD-L1 and CTLA-4 expressing circulating T cells was increased in HNSCC patients compared to healthy donors, again pointing towards elevated proportions of regulatory or exhausted T-cell phenotypes in HNSCC patients. Taken together, these results clearly demonstrate the importance of a comprehensive analysis of immune checkpoint expression on tumor-infiltrating and circulating lymphocytes to identify their impact on response to treatment in future studies targeting these pathways.

Recently, differences in the immune infiltrate between HPV positive and HPV negative tumors have been described. HPV positive tumors are characterized by an adaptive host immune response directed against viral antigens as well as specific $\mathrm{T}$ cells directed against viral proteins $[4,52,53]$. Further studies demonstrated a higher number of $\mathrm{CD}^{+} \mathrm{T}$ cells and a decreased $\mathrm{CD} 4 / \mathrm{CD} 8$ ratio in p16-positive patients $[48,53]$. We found a significantly higher number of $\mathrm{CD} 45^{+}$lymphocytes in HPV positive HNSCC than in HPV negative tumors. This finding may reflect the adaptive immune response against HPV antigens as well as a tumor-specific immune response. However, the relative proportion of T-cell subsets did not significantly differ between HPV positive and HPV negative tumors. There was a trend towards a higher number of tumor-infiltrating Treg in HPV negative tumors, which might correspond to a more immunosuppressive tumor microenvironment in HPV negative tumors. In this study, certain differences did not reach significance or might have been missed due to the number of analyzed PBMC or tumor samples $(n=34)$ and especially the highly heterogeneous distribution of T-cell subsets and immune checkpoint molecule expression.

PD-1 expression in TILs of HPV positive tumors was higher than in HPV negative tumors. This finding might reflect the fact that viral proteins induce a strong immune response represented by tumor-infiltrating memory $\mathrm{T}$ cells and PD- $1^{+} \mathrm{T}$ cells. This hypothesis is supported by recent data showing higher expression of PD-1 mRNA in HPV positive tumors [48]. However, a recent study also demonstrated high levels of PD-1 and PD-L1 expression in HPV negative HNSCC [54]. Our results confirm previous findings that PD-L1 expression in TILs does not differ between HPV positive and HPV negative patients [55]. CTLA-4 expression in HPV positive HNSCC was lower than in HPV negative tumors. This is in line with the finding that regulatory T cells, as highly CTLA-4 expressing cells were similarly less frequent in HPV positive tumors.

Clinical trials applying anti-PD-1 inhibitors showed activity regardless of HPV status in HNSCC [25, 56].
Since we found elevated checkpoint molecule expression in HPV positive and negative HNSCC, our results strongly support further evaluation of immune checkpoint inhibitors regardless of HPV status. Analysis of tumorassociated lymphocytes in HNSCC patients treated with immune checkpoint inhibitors could give further insights into the mode of action and factors determining response to these treatments. Recent studies in melanoma patients also suggest that the 'Immunoscore' can be a useful tool in predicting response to checkpoint inhibition [57]. In view of this finding, we established an automated analysis covering the entire cross section of HNSCC tumors and investigating $\mathrm{CD}^{+}$and $\mathrm{CD}^{+}$cell densities in HNSCC. Given the often highly heterogeneous immune cell infiltration in different areas of the same HNSCC, the entire area of tumor core and invasive margin in one slide was included. In our opinion, this provides more reliable and consistent results than the analysis of tissue microarrays, which use only small, potentially not representative proportions of the tumor. Results were highly concordant with flow-cytometric analysis of the same tumors. In HPV negative HNSCC, high $\mathrm{CD}^{+}$and $\mathrm{CD}^{+}$cell infiltration was mainly observed in tumors with increased levels of MHC class I expression on tumor cells, suggesting a recognition of MHC I-presented tumor antigens by infiltrating $\mathrm{T}$ cells, which is supported by previous findings that TILs from HNSCC comprise tumorspecific T cells [58]. This is particularly important, since response to checkpoint inhibitors is related to pre-existing antitumor T-cell activity [59]. Whether the 'Immunoscore' and especially the combination with flow-cytometric analyses, has prognostic relevance and a predictive value regarding immunotherapy of HNSCC will be in the focus of future investigations.

Taken together, our results show a substantial rate of regulatory $\mathrm{T}$ cells and expression of immune inhibitory checkpoint molecules reflecting an immunosuppressive environment in HNSCC. HPV status is not related to alterations of T-cell subsets or profound differences in immune checkpoint molecule expression. In-depth analysis of tumor-associated immune cells and checkpoint molecule expression could prove useful in clinical routine in the future, especially since reliable predictive markers for treatment response to immune checkpoint inhibitors are still lacking.

\section{MATERIALS AND METHODS}

\section{Patient characteristics}

Tumor samples $(n=34)$, peripheral blood mononuclear cells (PBMC; $n=34)$ and random biopsies from macroscopically non-cancerous mucosa $(n=7)$ of 34 patients with diagnosed squamous cell carcinoma of the head and neck were obtained between 2013 and 2016. Importantly, all samples were acquired before any kind 
of anticancer therapy was initialized. Tumor stage was assessed according to the UICC tumor-node-metastasis criteria (7th edition). Peripheral blood samples of 15 healthy donors were included as controls for PBMCs. The patient characteristics are summarized in Table 1. Written informed consent was obtained from all patients prior to surgery and from all healthy donors. Our institutional review board approved the study (protocol no. 11-116).

\section{Cell isolation from human peripheral blood and tumor}

Peripheral blood was obtained from patients and age- and sex-matched healthy donors immediately prior to surgery. PBMC were purified using density-based separation with Pancoll Human (PAN-Biotech, Cat. No. P04-60100). Fresh unfixed tissue from primary tumors or non-cancerous mucosa, which was not required for pathological analyses, was processed immediately after tumor biopsy or surgical resection. Fresh tissue was manually minced and transferred into single cells suspensions using a gentleMACS Dissociator (Miltenyi) with DNase I (100U/mL, Applichem; Cat. No. A3778) and Collagenase IV $(320 \mathrm{u} / \mathrm{mL}$, Worthington; Cat. No. LS004180). Cells were filtered through $100 \mu \mathrm{m}$ and 70 $\mu \mathrm{m}$ nylon cell strainers (Greiner Bio-One; Cat. No. 89508344 and 89508-340).

\section{Flow cytometry}

At least $5 \times 10^{5}$ events per sample were acquired on a Gallios 10-color flow cytometer (Beckman Coulter). Phenotypic characterization of T-cell subsets was performed using CD3-APC-Cy7, CD39-APC, CTLA-4$\mathrm{PE}$ (all BD Biosciences), CD4-PerCP/Cy5.5, CD8-PE/ Cy7, PD-1-APC, PD-L1-PE/Cy7, CCR7-FITC, CD25AF700, CD127-PerCP/Cy5.5, CD45RA-AF700 (all Biolegend), CD45-PE-eFluor610 (eBioscience) and aqua dead cell stain (Life Technologies).

\section{Immunohistochemistry}

Immunohistochemical staining was performed on formaldehyde-fixed, paraffin-embedded tissue sections of $3 \mu \mathrm{m}$ thickness using monoclonal mouse anti-human primary antibodies for MHC class I (Clone EMR8-5; Abcam; Cat. No. AB70328), CD8 (Clone C8/144B; Dako; Cat. No. M710301-2) and P16 ${ }^{\mathrm{INK} 4 \mathrm{~A}}$ (Clone G175-405; BD Biosciences; Cat. No. 550834) and rabbit anti-human antibody for CD3 (Thermo Scientific; Cat. No. MA190582) followed by appropriate biotinylated secondary antibodies. Every analysis contained negative and positive controls. Detection of secondary antibodies was achieved by avidin-biotin-peroxidase complex (ABC) method using the Vectastain-Elite-ABC kit (Vector Laboratories; Cat. No. PK-6100). Diaminobenzidine tetrahydrochloride $/ \mathrm{H}_{2} \mathrm{O}_{2}$ was used to visualize peroxidase activity, hematoxylin as nuclear counterstaining. Strong cytoplasmic and nuclear staining was regarded positive for $\mathrm{p} 16$ expression. $\mathrm{MHC}$ class I expression was classified as high, if more than $80 \%$ of tumor cells showed strong staining, otherwise it was classified as low MHC class I expression.

\section{DNA isolation, HPV-DNA detection by PCR and HPV typing}

DNA was extracted from paraffin-embedded tissue samples using the Gentra Puregene Tissue kit with proteinase $\mathrm{K}$ treatment (Qiagen) according to the manufacturer's protocol.

Nested PCR was performed to detect HPV DNA as described previously [60]. After purification (QIAquick PCR Purification kit, Qiagen; Cat. No. 28104), A6/ $\mathrm{A} 8$ and $\mathrm{GP}^{+} / \mathrm{GP}^{+} \mathrm{PCR}$ products were sequenced (LIGHTRUN $^{\text {TM }}$ ) by GATC Biotech using the A6 or GP5 ${ }^{+}$ primer, respectively. HPV subtypes were identified by comparing the sequencing results to the NCBI database entries (NCBI BLAST alignment).

\section{Automated analysis of CD3/CD8 cell density}

FFPE (formalin-fixed, paraffin-embedded) sections covering the whole cross section of the primary tumor including sufficient adjacent tissue from 16 surgically treated HNSCC patients were selected for immunohistochemical analysis of CD3 and CD8. Highresolution images (20x objective) were captured using a SCN400 slide scanner (Leica Biosystems). Image preprocessing was performed with Aperio ImageScope software (Leica Biosystems) and GNU Image Manipulation Program (version 2). Tumor borders were delineated by an experienced pathologist. The area of the invasive margin (IM) was determined as ranging from $50 \mu \mathrm{m}$ within the tumor measured from the tumor border to $300 \mu \mathrm{m}$ outside the tumor border. Tumor core (CT) comprised the whole tumor section excluding the first $50 \mu \mathrm{m}$ adjacent to the tumor border. Necrotic areas were excluded from analysis. IM and CT sections were separated and cropped into tiles of $1024 \times 1024$ pixels utilizing OpenSlide Python and the libvips image processing library [61, 62]. Automated analysis of DAB-positive cells per area was performed using CellProfiler software (version 2.1.1). A schematic overview of the analyzing process is depicted in Figure 2B. Counting accuracy was verified by optical counting of selected tissue areas. Using the median $\mathrm{CD}^{+}$or $\mathrm{CD}^{+}$ cell density of all analyzed samples as cut-off value, samples were classified as $\mathrm{CD} 3^{\text {high }}$ or $\mathrm{CD} 3^{\text {low }}$ and $\mathrm{CD} 8^{\text {high }}$ or CD8 ${ }^{\text {low }}$, respectively. IM and CT were analyzed separately. Subsequently, tumors were subdivided into five groups (0IV) according to their $\mathrm{CD}^{+}$and $\mathrm{CD}^{+}$cell infiltration of IM and CT as described previously [20]. Subgroups 0-I were termed 'Immunoscore low', III-IV 'Immunoscore high'. 


\section{Data analysis}

Unless otherwise stated, data is shown as mean \pm standard deviation. Samples with cell count below a threshold of 500 detected $\mathrm{T}$ cells per analysis were excluded from further subset analysis. Flow cytometry data was analyzed using the Kaluza Software (Version 1.1, Beckman Coulter) and GraphPad Prism 7 (GraphPad Software). Shapiro-Wilk test and Levene's test were applied to test for normality and homoscedasticity, respectively. In case of normal distribution and homoscedasticity, one-way ANOVA was performed to compare independent measures of more than two groups and Student's $t$-test for comparison of two groups. Otherwise, non-parametric Mann-Whitney or KruskalWallis tests were used for comparisons of two or more than two groups, respectively. Fisher's exact test was applied to test for association between categorical variables.

\section{Abbreviations}

$\mathrm{ABC}=$ avidin-biotin-peroxidase complex; ANOVA $=$ analysis of variance; $\mathrm{CT}=$ tumor core; $\mathrm{CTLA}-4=$ cytotoxic T-lymphocyte-associated antigen 4; DAB $=3,3^{\prime}$-diaminobenzidine; DNA $=$ deoxyribonucleic acid; FFPE = formalin-fixed, paraffin-embedded; HC $=$ healthy control; $\mathrm{HNSCC}=$ head and neck squamous cell carcinoma; HPV = human papillomavirus; IM $=$ invasive margin; $\mathrm{MHC}=$ major histocompatibility complex; mRNA = messenger ribonucleic acid; $\mathrm{PBMC}=$ peripheral blood mononuclear cells; $\mathrm{PCR}=$ polymerase chain reaction; PD-1 = programmed cell death 1 ; PD-L1 = programmed cell death 1 ligand $1 ; \mathrm{TIL}=$ tumor-infiltrating lymphocytes; Treg = regulatory $\mathrm{T}$ cells; $\mathrm{UICC}=$ Union for International Cancer Control

\section{Authors' contributions}

Conception and study design: AL, HS, MBB, DB; Development of methodology: AL, HS, ASV, ST, PZ, AS, JI, TH; Acquisition of data: AL, HS, SIR, MT, SR, $\mathrm{KW}, \mathrm{MGM}, \mathrm{LT}, \mathrm{CH}$; Analysis and interpretation of data: AL, HS, SIR, PZ, LT, AQ, MBB; Writing and review of the manuscript: AL, HS, SIR, KW, MBB, DB; Study supervision: $\mathrm{MBB}, \mathrm{DB}$.

\section{CONFLICTS OF INTEREST}

The authors have no conflicts of interest related to this manuscript.

\section{FINANCIAL SUPPORT}

Supported by the Koeln Fortune Program / Faculty of Medicine, University of Cologne (to AL), Jean-
Uhrmacher-Institute for Clinical ENT Research (to AL), a 'GEROK' local research grant (to AL) and 'Freie Akademische Gesellschaft Basel’ (to SIR).

\section{REFERENCES}

1. Ramroth H, Dietz A, Becher H. Interaction effects and population-attributable risks for smoking and alcohol on laryngeal cancer and its subsites. A case-control study from Germany. Methods Inf Med. 2004; 43:499-504. doi: 10.1267/METH04050499.

2. Mehanna H, Beech $T$, Nicholson T, El-Hariry I, McConkey C, Paleri V, Roberts S. Prevalence of human papillomavirus in oropharyngeal and nonoropharyngeal head and neck cancer--systematic review and meta-analysis of trends by time and region. Head Neck. 2013; 35:747-55. doi: 10.1002/hed.22015.

3. Ang KK, Harris J, Wheeler R, Weber R, Rosenthal DI, Nguyen-Tân PF, Westra WH, Chung CH, Jordan RC, Lu C, Kim H, Axelrod R, Silverman CC, et al. Human papillomavirus and survival of patients with oropharyngeal cancer. N Engl J Med. 2010; 363:24-35. doi: 10.1056/NEJMoa0912217.

4. Albers A, Abe K, Hunt J, Wang J, Lopez-Albaitero A, Schaefer C, Gooding W, Whiteside TL, Ferrone S, DeLeo A, Ferris RL. Antitumor activity of human papillomavirus type 16 E7-specific $\mathrm{T}$ cells against virally infected squamous cell carcinoma of the head and neck. Cancer Res. 2005; 65:11146-55. doi: 10.1158/0008-5472.CAN-05-0772.

5. Hanahan D, Weinberg RA. Hallmarks of cancer: the next generation. Cell. 2011; 144:646-74. doi: 10.1016/j. cell.2011.02.013.

6. Vesely MD, Kershaw MH, Schreiber RD, Smyth MJ. Natural innate and adaptive immunity to cancer. Annu Rev Immunol. 2011; 29:235-71. doi: 10.1146/annurevimmunol-031210-101324.

7. Schlößer HA, Drebber U, Kloth M, Thelen M, Rothschild SI, Haase S, Garcia-Marquez M, Wennhold K, Berlth F, Urbanski A, Alakus H, Schauss A, ShimabukuroVornhagen A, et al. Immune checkpoints programmed death 1 ligand 1 and cytotoxic T lymphocyte associated molecule 4 in gastric adenocarcinoma. Oncoimmunology. 2016; 5: e1100789. doi: 10.1080/2162402X.2015.1100789.

8. Shimabukuro-Vornhagen A, Schlosser HA, Gryschok L, Malcher J, Wennhold K, Garcia-Marquez M, Herbold T, Neuhaus LS, Becker HJ, Fiedler A, Scherwitz P, Koslowsky T, Hake R, et al. Characterization of tumor-associated B-cell subsets in patients with colorectal cancer. Oncotarget. 2014; 5:4651-64. doi: 10.18632/oncotarget.1701.

9. Woo EY, Yeh H, Chu CS, Schlienger K, Carroll RG, Riley JL, Kaiser LR, June CH. Cutting edge: Regulatory T cells from lung cancer patients directly inhibit autologous $\mathrm{T}$ cell proliferation. J Immunol. 2002; 168:4272-6.

10. Woo EY, Chu CS, Goletz TJ, Schlienger K, Yeh H, Coukos G, Rubin SC, Kaiser LR, June CH. Regulatory 
$\mathrm{CD} 4(+) \mathrm{CD} 25(+) \mathrm{T}$ cells in tumors from patients with earlystage non-small cell lung cancer and late-stage ovarian cancer. Cancer Res. 2001; 61:4766-72.

11. Liyanage UK, Moore TT, Joo HG, Tanaka Y, Herrmann V, Doherty G, Drebin JA, Strasberg SM, Eberlein TJ, Goedegebuure PS, Linehan DC. Prevalence of regulatory $\mathrm{T}$ cells is increased in peripheral blood and tumor microenvironment of patients with pancreas or breast adenocarcinoma. J Immunol. 2002; 169:2756-61.

12. Wolf AM, Wolf D, Steurer M, Gastl G, Gunsilius E, Grubeck-Loebenstein B. Increase of regulatory T cells in the peripheral blood of cancer patients. Clin Cancer Res. 2003; 9:606-12.

13. Whiteside TL. Down-regulation of zeta-chain expression in T cells: a biomarker of prognosis in cancer? Cancer Immunol Immunother. 2004; 53:865-78. doi: 10.1007/ s00262-004-0521-0.

14. Wallis SP, Stafford ND, Greenman J. Clinical relevance of immune parameters in the tumor microenvironment of head and neck cancers. Head Neck. 2015; 37:449-59. doi: 10.1002/hed.23736.

15. Strauss L, Bergmann C, Szczepanski M, Gooding W, Johnson JT, Whiteside TL. A unique subset of CD4+CD25highFoxp3 $+\mathrm{T}$ cells secreting interleukin-10 and transforming growth factor-beta1 mediates suppression in the tumor microenvironment. Clin Cancer Res. 2007; 13:4345-54. doi: 10.1158/1078-0432.CCR-07-0472.

16. Badoual C, Hans S, Rodriguez J, Peyrard S, Klein C, Agueznay Nel H, Mosseri V, Laccourreye O, Bruneval P, Fridman WH, Brasnu DF, Tartour E. Prognostic value of tumor-infiltrating CD4+ T-cell subpopulations in head and neck cancers. Clin Cancer Res. 2006; 12:465-72. doi: 10.1158/1078-0432.CCR-05-1886.

17. Galon J, Costes A, Sanchez-Cabo F, Kirilovsky A, Mlecnik B, Lagorce-Pagès C, Tosolini M, Camus M, Berger A, Wind P, Zinzindohoué F, Bruneval P, Cugnenc PH, et al. Type, density, and location of immune cells within human colorectal tumors predict clinical outcome. Science. 2006; 313:1960-4. doi: 10.1126/science.1129139.

18. Mlecnik B, Bindea G, Angell HK, Maby P, Angelova M, Tougeron D, Church SE, Lafontaine L, Fischer M, Fredriksen T, Sasso M, Bilocq AM, Kirilovsky A, et al. Integrative Analyses of Colorectal Cancer Show Immunoscore Is a Stronger Predictor of Patient Survival Than Microsatellite Instability. Immunity. 2016; 44:698711. doi: 10.1016/j.immuni.2016.02.025.

19. Pagès F, Kirilovsky A, Mlecnik B, Asslaber M, Tosolini M, Bindea G, Lagorce C, Wind P, Marliot F, Bruneval P, Zatloukal K, Trajanoski Z, Berger A, et al. In Situ Cytotoxic and Memory T Cells Predict Outcome in Patients With Early-Stage Colorectal Cancer. J Clin Oncol. 2009; 27:5944-51. doi: 10.1200/JCO.2008.19.6147.

20. Galon J, Mlecnik B, Bindea G, Angell HK, Berger A, Lagorce C, Lugli A, Zlobec I, Hartmann A, Bifulco C, Nagtegaal ID, Palmqvist R, Masucci GV, et al. Towards the introduction of the "Immunoscore" in the classification of malignant tumours. J Pathol. 2014; 232:199-209. doi: 10.1002/path.4287.

21. Perea F, Bernal M, Sánchez-Palencia A, Carretero J, Torres C, Bayarri C, Gómez-Morales M, Garrido F, RuizCabello F. The absence of HLA class I expression in nonsmall cell lung cancer correlates with the tumor tissue structure and the pattern of $\mathrm{T}$ cell infiltration. Int J Cancer. 2017; 140:888-99. doi: 10.1002/ijc.30489.

22. Näsman A, Andersson E, Nordfors C, Grün N, Johansson H, Munck-Wikland E, Massucci G, Dalianis T, Ramqvist T. MHC class I expression in HPV positive and negative tonsillar squamous cell carcinoma in correlation to clinical outcome. Int J Cancer. 2013; 132:72-81. doi: 10.1002/ijc.27635.

23. Pardoll DM. The blockade of immune checkpoints in cancer immunotherapy. Nat Rev Cancer. 2012; 12:252-64. doi: $10.1038 /$ nrc3239.

24. Fife BT, Bluestone JA. Control of peripheral T-cell tolerance and autoimmunity via the CTLA-4 and PD-1 pathways. Immunol Rev. 2008; 224:166-82. doi: 10.1111/j.1600065X.2008.00662.x.

25. Ferris RL, Blumenschein G, Fayette J, Guigay J, Colevas AD, Licitra L, Harrington K, Kasper S, Vokes EE, Even C, Worden F, Saba NF, Iglesias Docampo LC, et al. Nivolumab for Recurrent Squamous-Cell Carcinoma of the Head and Neck. N Engl J Med. 2016; 375:1856-67. doi: 10.1056/NEJMoa1602252.

26. Mandapathil M, Lang S, Gorelik E, Whiteside TL. Isolation of functional human regulatory $\mathrm{T}$ cells (Treg) from the peripheral blood based on the CD39 expression. J Immunol Methods. 2009; 346:55-63. doi: 10.1016/j.jim.2009.05.004.

27. Yu N, Li X, Song W, Li D, Yu D, Zeng X, Li M, Leng X, Li X. CD4+CD25+CD127low/- T Cells: A More Specific Treg Population in Human Peripheral Blood. Inflammation. 2012; 35:1773-80. doi: 10.1007/s10753-012-9496-8.

28. Beyer M, Classen S, Endl E, Kochanek M, Weihrauch MR, Debey-Pascher S, Knolle PA, Schultze JL, Beyer M, Classen S, Endl E, Kochanek M, Weihrauch MR, et al. Comparative approach to define increased regulatory $\mathrm{T}$ cells in different cancer subtypes by combined assessment of CD127 and FOXP3. Clin Dev Immunol. 2011; 2011: 734036. doi: 10.1155/2011/734036.

29. Li H, Ou X, Xiong J, Wang T. HPV16E7 mediates HADC chromatin repression and downregulation of MHC class I genes in HPV16 tumorigenic cells through interaction with an MHC class I promoter. Biochem Biophys Res Commun. 2006; 349:1315-21. doi: 10.1016/j.bbrc.2006.08.182.

30. Pretscher D, Distel LV, Grabenbauer GG, Wittlinger M, Buettner M, Niedobitek G. Distribution of immune cells in head and neck cancer: CD8+ T-cells and CD20+ B-cells in metastatic lymph nodes are associated with favourable outcome in patients with oro- and hypopharyngeal carcinoma. BMC Cancer. 2009; 9: 292. doi: 10.1186/14712407-9-292. 
31. Russell S, Angell T, Lechner M, Liebertz D, Correa A, Sinha U, Kokot N, Epstein A. Immune cell infiltration patterns and survival in head and neck squamous cell carcinoma. Head Neck Oncol. 2013; 5: 24.

32. Nguyen N, Bellile E, Thomas D, McHugh J, Rozek L, Virani S, Peterson L, Carey TE, Walline H, Moyer J, Spector M, Perim D, Prince M, et al. Tumor infiltrating lymphocytes and survival in patients with head and neck squamous cell carcinoma. Head Neck. 2016; 38:1074-84. doi: 10.1002/hed.24406.

33. Gooden MJ, de Bock GH, Leffers $\mathrm{N}$, Daemen $\mathrm{T}$, Nijman HW. The prognostic influence of tumour-infiltrating lymphocytes in cancer: a systematic review with metaanalysis. Br J Cancer. 2011; 105:93-103. doi: 10.1038/ bjc.2011.189.

34. Ogino S, Nosho K, Irahara N, Meyerhardt JA, Baba Y, Shima K, Glickman JN, Ferrone CR, Mino-Kenudson M, Tanaka N, Dranoff G, Giovannucci EL, Fuchs CS. Lymphocytic reaction to colorectal cancer is associated with longer survival, independent of lymph node count, microsatellite instability, and $\mathrm{CpG}$ island methylator phenotype. Clin Cancer Res. 2009; 15:6412-20. doi: 10.1158/1078-0432.CCR-09-1438.

35. de Miranda NF, Goudkade D, Jordanova ES, Tops CM, Hes FJ, Vasen HF, van Wezel T, Morreau H. Infiltration of Lynch colorectal cancers by activated immune cells associates with early staging of the primary tumor and absence of lymph node metastases. Clin Cancer Res. 2012; 18:1237-45. doi: 10.1158/1078-0432.CCR-11-1997.

36. Balermpas P, Michel Y, Wagenblast J, Seitz O, Weiss C, Rödel F, Rödel C, Fokas E. Tumour-infiltrating lymphocytes predict response to definitive chemoradiotherapy in head and neck cancer. Br J Cancer. 2014; 110:501-9. doi: 10.1038/bjc.2013.640.

37. Ward MJ, Thirdborough SM, Mellows T, Riley C, Harris S, Suchak K, Webb A, Hampton C, Patel NN, Randall CJ, Cox HJ, Jogai S, Primrose J, et al. Tumour-infiltrating lymphocytes predict for outcome in HPV-positive oropharyngeal cancer. Br J Cancer. 2014; 110:489-500. doi: 10.1038/bjc.2013.639.

38. Kuss I, Donnenberg AD, Gooding W, Whiteside TL. Effector CD8+CD45RO-CD27-T cells have signalling defects in patients with squamous cell carcinoma of the head and neck. Br J Cancer. 2003; 88:223-30. doi: 10.1038/ sj.bjc. 6600694 .

39. Schaefer C, Kim GG, Albers A, Hoermann K, Myers EN, Whiteside TL. Characteristics of CD4+CD25+ regulatory T cells in the peripheral circulation of patients with head and neck cancer. Br J Cancer. 2005; 92:913-20. doi: 10.1038/ sj.bjc. 6602407 .

40. Jie HB, Gildener-Leapman N, Li J, Srivastava RM, Gibson SP, Whiteside TL, Ferris RL. Intratumoral regulatory $\mathrm{T}$ cells upregulate immunosuppressive molecules in head and neck cancer patients. Br J Cancer. 2013; 109:2629-35. doi: 10.1038/bjc.2013.645.
41. Whiteside TL. What are regulatory T cells (Treg) regulating in cancer and why? Semin Cancer Biol. 2012; 22:327-34. doi: 10.1016/j.semcancer.2012.03.004.

42. Melero I, Hervas-Stubbs S, Glennie M, Pardoll DM, Chen L. Immunostimulatory monoclonal antibodies for cancer therapy. Nat Rev Cancer. 2007; 7:95-106. doi: $10.1038 /$ nrc2051.

43. Mueller SN, Ahmed R. High antigen levels are the cause of $\mathrm{T}$ cell exhaustion during chronic viral infection. Proc Natl Acad Sci USA. 2009; 106:8623-8. doi: 10.1073/ pnas.0809818106.

44. Wherry EJ. T cell exhaustion. Nat Immunol. 2011; 12:492-9.

45. Yi JS, Cox MA, Zajac AJ. T-cell exhaustion: characteristics, causes and conversion. Immunology. 2010; 129:474-81. doi: 10.1111/j.1365-2567.2010.03255.x.

46. Jiang Y, Li Y, Zhu B. T-cell exhaustion in the tumor microenvironment. Cell Death Dis. 2015; 6: e1792. doi: 10.1038/cddis.2015.162.

47. Badoual C, Hans S, Merillon N, Van Ryswick C, Ravel P, Benhamouda N, Levionnois E, Nizard M, Si-Mohamed A, Besnier N, Gey A, Rotem-Yehudar R, Pere H, et al. PD1-Expressing Tumor-Infiltrating $\mathrm{T}$ Cells Are a Favorable Prognostic Biomarker in HPV-Associated Head and Neck Cancer. Cancer Res. 2013; 73:128-38. doi: 10.1158/00085472.CAN-12-2606.

48. Partlová S, Bouček J, Kloudová K, Lukešová E, Zábrodský M, Grega M, Fučíková J, Truxová I, Tachezy R, Špíšek R, Fialová A. Distinct patterns of intratumoral immune cell infiltrates in patients with HPV-associated compared to non-virally induced head and neck squamous cell carcinoma. Oncoimmunology. 2015; 4: e965570. doi: 10.4161/21624011.2014.965570.

49. Lin YM, Sung WW, Hsieh MJ, Tsai SC, Lai HW, Yang SM, Shen KH, Chen MK, Lee H, Yeh KT, Chen CJ. High PD-L1 Expression Correlates with Metastasis and Poor Prognosis in Oral Squamous Cell Carcinoma. PLoS One. 2015; 10: e0142656. doi: 10.1371/journal.pone.0142656.

50. Brahmer J, Reckamp KL, Baas P, Crinò L, Eberhardt WE, Poddubskaya E, Antonia S, Pluzanski A, Vokes EE, Holgado E, Waterhouse D, Ready N, Gainor J, et al. Nivolumab versus Docetaxel in Advanced SquamousCell Non-Small-Cell Lung Cancer. N Engl J Med. 2015; 373:123-35. doi: 10.1056/NEJMoa1504627.

51. Larkin J, Chiarion-Sileni V, Gonzalez R, Grob JJ, Cowey CL, Lao CD, Schadendorf D, Dummer R, Smylie M, Rutkowski P, Ferrucci PF, Hill A, Wagstaff J, et al. Combined Nivolumab and Ipilimumab or Monotherapy in Untreated Melanoma. N Engl J Med. 2015; 373:23-34. doi: 10.1056/NEJMoa1504030.

52. Wansom D, Light E, Thomas D, Worden F, Prince M, Urba S, Chepeha D, Kumar B, Cordell K, Eisbruch A, Taylor J, Moyer J, Bradford C, et al. Infiltrating lymphocytes and human papillomavirus-16--associated oropharyngeal cancer. Laryngoscope. 2012; 122:121-7. doi: 10.1002/lary.22133. 
53. Wansom D, Light E, Worden F, Prince M, Urba S, Chepeha DB, Cordell K, Eisbruch A, Taylor J, D'Silva N, Moyer J, Bradford CR, Kurnit D, et al. Correlation of cellular immunity with human papillomavirus 16 status and outcome in patients with advanced oropharyngeal cancer. Arch Otolaryngol Head Neck Surg. 2010; 136:1267-73. doi: 10.1001/archoto.2010.211.

54. Malm IJ, Bruno TC, Fu J, Zeng Q, Taube JM, Westra W, Pardoll D, Drake CG, Kim YJ. Expression profile and in vitro blockade of programmed death-1 in human papillomavirus-negative head and neck squamous cell carcinoma. Head Neck. 2015; 37:1088-95. doi: 10.1002/ hed.23706.

55. Kim HS, Lee JY, Lim SH, Park K, Sun JM, Ko YH, Baek CH, Son Y, Jeong HS, Ahn YC, Lee MY, Hong M, Ahn MJ. Association Between PD-L1 and HPV Status and the Prognostic Value of PD-L1 in Oropharyngeal Squamous Cell Carcinoma. Cancer Res Treat. 2015; 48:527-36. doi: 10.4143/crt.2015.249.

56. Seiwert TY, Haddad RI, Gupta S, Mehra R, Tahara M, Berger R, Lee SH, Burtness B, Le DT, Heath K, Blum A, Dolled-Filhart M, Emancipator K, et al. Antitumor Activity of the Anti-PD-1 Antibody Pembrolizumab in BiomarkerUnselected Patients with R/M Head and Neck Cancer: Preliminary Results from KEYNOTE-012 Expansion Cohort. J Clin Oncol. 2015; 33:abstr LBA6008.

57. Kirilovsky A, Marliot F, El Sissy C, Haicheur N, Galon J, Pagès F. Rational bases for the use of the Immunoscore in routine clinical settings as a prognostic and predictive biomarker in cancer patients. Int Immunol. 2016; 28:20-40. doi: 10.1093/intimm/dxw021.
58. Junker N, Kvistborg P, Køllgaard T, Straten P thor, Andersen MH, Svane IM. Tumor associated antigen specific T-cell populations identified in ex vivo expanded TIL cultures. Cell Immunol. 2012; 273:1-9. doi: 10.1016/j. cellimm.2011.12.004.

59. Herbst RS, Soria JC, Kowanetz M, Fine GD, Hamid O, Gordon MS, Sosman JA, McDermott DF, Powderly JD, Gettinger SN, Kohrt HE, Horn L, Lawrence DP, et al. Predictive correlates of response to the anti-PD-L1 antibody MPDL3280A in cancer patients. Nature. 2014; 515:563-7. doi: 10.1038/nature14011.

60. Wieland U, Ritzkowsky A, Stoltidis M, Weissenborn S, Stark S, Ploner M, Majewski S, Jablonska S, Pfister HJ, Fuchs PG. Papillomavirus DNA in basal cell carcinomas of immunocompetent patients: an accidental association? J Invest Dermatol. 2000; 115:124-8. doi: 10.1046/j.15231747.2000.00015.x.

61. Goode A, Gilbert B, Harkes J, Jukic D, Satyanarayanan M. OpenSlide: A vendor-neutral software foundation for digital pathology. J Pathol Inform. 2013; 4: 27. doi: 10.4103/21533539.119005.

62. Martinez K, Cupitt J. VIPS - a highly tuned image processing software architecture. IEEE International Conference on Image Processing 2005. IEEE; 2005. p. II574. doi: 10.1109/ICIP.2005.1530120. 